\title{
WestVirginiaUniversity
}

THE RESEARCH REPOSITORY @ WVU

Graduate Theses, Dissertations, and Problem Reports

2014

\section{Corridos, Drugs, and Violence: An Analysis of Mexican Drug Ballads}

\author{
Kristen L. Richmond
}

Follow this and additional works at: https://researchrepository.wvu.edu/etd

\section{Recommended Citation}

Richmond, Kristen L., "Corridos, Drugs, and Violence: An Analysis of Mexican Drug Ballads" (2014). Graduate Theses, Dissertations, and Problem Reports. 7344.

https://researchrepository.wvu.edu/etd/7344

This Thesis is protected by copyright and/or related rights. It has been brought to you by the The Research Repository @ WVU with permission from the rights-holder(s). You are free to use this Thesis in any way that is permitted by the copyright and related rights legislation that applies to your use. For other uses you must obtain permission from the rights-holder(s) directly, unless additional rights are indicated by a Creative Commons license in the record and/ or on the work itself. This Thesis has been accepted for inclusion in WVU Graduate Theses, Dissertations, and Problem Reports collection by an authorized administrator of The Research Repository @ WVU. For more information, please contact researchrepository@mail.wvu.edu. 
Corridos, Drugs, and Violence:

An Analysis of Mexican Drug Ballads

Kristen L. Richmond

Thesis submitted in partial fulfillment of the requirements for the degree of

Master of Arts in Spanish

Pablo Garcia Loaeza, Ph.D., Chair

Victoria Garrett, Ph.D

James Siekmeier, Ph.D

Department of World Languages, Literatures, and Linguistics

\author{
West Virginia University \\ Morgantown, West Virginia \\ April 2014
}

Keywords: Narcocorrido, drug ballad, Mexico, drug trafficking, violence, music, banda, gangsta rap

Copyright 2013 Kristen L. Richmond 
UMI Number: 1555000

All rights reserved

INFORMATION TO ALL USERS

The quality of this reproduction is dependent upon the quality of the copy submitted.

In the unlikely event that the author did not send a complete manuscript and there are missing pages, these will be noted. Also, if material had to be removed, a note will indicate the deletion.

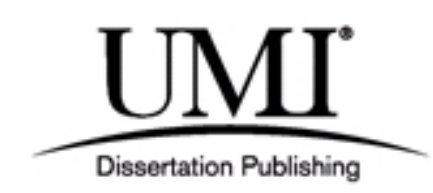

UMI 1555000

Published by ProQuest LLC (2014). Copyright in the Dissertation held by the Author.

Microform Edition () ProQuest LLC.

All rights reserved. This work is protected against unauthorized copying under Title 17, United States Code

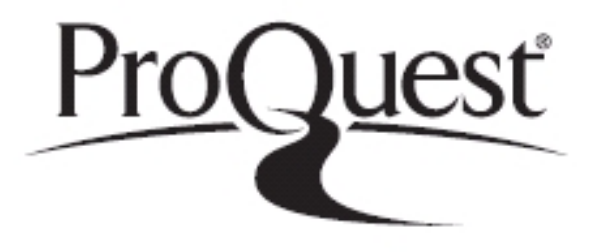

ProQuest LLC.

789 East Eisenhower Parkway

P.O. Box 1346

Ann Arbor, MI 48106 - 1346 


\author{
ABSTRACT \\ Corridos, Drugs, and Violence: \\ An Analysis of Mexican Drug Ballads
}

Kristen L. Richmond

Narcocorridos, or Mexican drug ballads, are a contemporary form of the corrido connected to banda music in the northern part of Mexico and along the border in the United States. The narcocorrido is sometimes compared to gangsta rap due to its exciting narratives of drug traffickers who rose above poor socio-economic conditions to become powerful and wealthy figures in the drug trade. The stories reflected in Mexican drug ballads highlight the lifestyle of drug lords and aspects of the drug trade that are imbued with violence. Narcocorrido lyrics focus on misfortunes and death while referencing events related to illegal criminal activities of the drug trade. Violent depictions have led to narcocorridos being banned in parts of Mexico and the United States. However, narcocorridos are rather mild in comparison to the hyper-violence that is experienced in real, everyday life as a result of drug trafficking. Narcocorridos are not a cause of drug trafficking, instead they are an effect or aspect of narcocultura. 
Table of Contents

\section{Introduction}

i. "The Code of the Street" - Elijah Anderson .............. 1

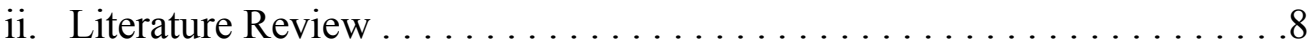

\section{Historical Context}

i. Mexico: A History of Violence . . . . . . . . . . . . . . . . . 13

ii. Mexico and the United States: The "War on Drugs" . . . . . . . . . . . . 19

\section{Narcocorrido Analyses}

i. Socio-Economic Factors in the Composition and Distribution of Narcocorridos ................................ 31

ii. Representation of Drug Traffickers, Their Attitudes toward Crime and Death, and the Code of the Street in Narcocorrido Narratives . . . . . . 36 iii. The Representation of Women in Narcocorridos . . . . . . . . . . . . . . .48

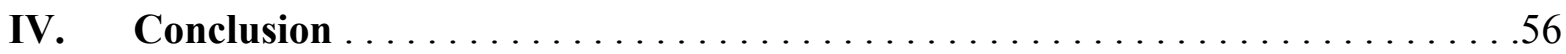

V. Appendix I

i. Narcocorrido Lyrics . . . . . . . . . . . . . . . . . . . . 62

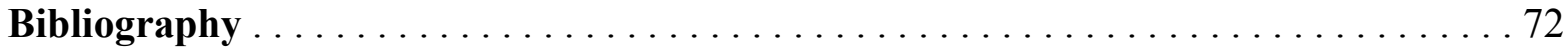


CHAPTER I

INTRODUCTION:

NARCOCULTURE, DRUG BALLADS, AND SOCIAL IDENTITY

\section{The Code of the Street}

In his book The Code of the Street, Elijah Anderson (1999) explores problems that poor, inner-city black communities face and how they become integrated into one's identity, specifically issues of violence and aggression. Anderson argues that violence is dually promoted and condoned by what he refers to as the street code, a type of social order that has emerged in disadvantaged communities. An important feature of the street code is respect. One of the most common and effective ways to earn respect is by developing a reputation based upon violence (Anderson 1999; 66-67). In other words, a person's propensity to engage in violent altercations is directly correlated with developing an individual's social status and gaining and/or maintaining respect among those who participate in street culture. A violent reputation promotes the deterrence of future assaults or acts that "challenge" an individual. However, this does not entirely eliminate the possibility of attacks or acts of aggression against someone who follows informal rules of the street. In certain circumstances, according to the street code, the use of violence is warranted and in most cases even obligatory and accepted. If an individual who has been confronted by an aggressor and fails to respond he would risk being viewed as weak, thus opening the door to future assaults. In other words, if an individual does not react, he risks losing his street credibility and status (Anderson 1999; 7). In order to maintain one's status and honor, the street code requires an individual to ensure that others perceive him as someone who is not to be messed with due to their proclivity and history to react in a violent manner (Anderson 1999; 73). 
Another aspect of the street code as it pertains to respect is the idea of what constitutes a man (Anderson 1999; 91). Masculinity is determined by how he is perceived by his peers, or even strangers, particularly with respect to violence. Responsibilities of males and how they should conduct themselves are instilled in them from a very young age. For example, males often hear "big boys don't cry," that crying is a female trait. Roles of men generally include those as a provider and protector. Such responsibilities are even thrust upon many young, adolescent males in the absence of a father figure who, in most instances, has fallen victim to the same cycle of violence. Many absent fathers are incarcerated, consumed by their involvement in street culture, or dead due to violence or drug use. As a result, young males are expected to fulfill responsibilities as "man of the house" such as to provide for, protect, and defend their families. Consequently, a large portion of the urban population is propelled into the dangerous, but lucrative life on the streets - drug dealing, prostitution, and other illegal activities.

Respect and masculinity are paramount in the perception of self for many of those who are intentionally or unintentionally governed by the code of the street. Thus, many will go to extreme measures to maintain these attributes. Many deem respect as an issue worth dying over because the concept of masculinity is a fundamental part of one's identity (Anderson 1999; 9293). In these parts of society, it is almost essential in the eyes of one's peers to enact vengeance on those responsible for any violent act against them. Retribution is considered an appropriate reaction to crime and is not necessarily considered a crime itself because it is pursuant of justice. Anderson states that this type of conflict management is considered a legitimate form of social control by many. Those who partake in it are determined to ensure that justice is carried out for the transgression, even if it means that they themselves will be defined as criminals or face retaliation, injury and/or death (Anderson 1999; 73). This type of violent social control is 
directly correlated with the availability and effectiveness of law enforcement. According to Anderson, the street code emerges where the influence of the police ends and personal responsibility for one's safety and well-being is felt to begin. As such, these types of crimes are more prevalent in areas where the protection of law is less accessible.

Drug trafficking has infiltrated social and cultural arenas, which has given rise to an oppositional culture commonly referred to as narcocultura, a culture obsessed with drugs, violence, and death. This subculture has evolved into a physical and cultural construct that many refer to as the "Drug War Zone" (Sullivan 2012). The physical dimension refers to 1) the geographical region(s) in which the drug war is fought between law enforcement and cartels and 2) violence associated with this conflict. Northern Mexico is the most violent part of the country due to its proximity to the United States, but other regions of the country have fallen under the control and influence of cartels. The most notable cartel-controlled and affected states include Sinaloa, Tamaulipas, Michoacán, Chihuahua, and Morelos. The cultural dimension is related to all aspects of society from politics, law, and ideology to education, television, and music. For example, a dedicated lexicon exists that refers to aspects of drug trafficking and narco-culture; terms such as: narcocine (narco-cinema), narcovida (narco-life), and narcotumbas (narcotombs), to name a few. This subculture has not only impregnated regions controlled by powerful Mexican cartels but has also permeated governmental institutions and has become popular in the streets (Wald 2001; 56). There are several circumstances that have fostered this type of narcoenvironment that are markedly similar to the type of social order that Anderson discusses - poor socio-economic conditions, police corruption, and violence. It must be noted that one factor is not more important than another, but rather the culmination of the three have all had an intrinsic effect on the presence, popularity, and influence of narco-culture. 
The power and influence of Mexican cartels can be attributed to a lack of faith in the police and judicial system due to corruption at all levels of government. Hence, criminals and cartels do not bare the sole responsibility of the violence and influence of drug trafficking. Political leaders and law enforcement officials also share the burden, as their participation or lack thereof influences the violent atmosphere and power of Mexican cartels. Some argue that the true enemy of the Mexican people is corruption because it exists at all levels of government. Following the murder of his son, Javier Sicilla, an award-winning poet, published a letter to Mexican politicians and criminals blaming them for the condition of the Mexican state. He scolds politicians for their complicity with drug traffickers and capos in their quest for money and power:

We have had it up to here with you, politicians - and when I say politicians I do not refer to any in particular, but, rather, a good part of you, including those who make up the political parties - because in your fight for power you have shamed the fabric of the nation. [...] We have had it up to here because the corruption of the judicial institutions generates the complicity with crime and the impunity to commit it, because in the middle of that corruption that demonstrates the failure of the State, each citizen of this country has been reduced to what the philosopher Giorgio Agamben called, using a Greek word, "zoe": an unprotected life, the life of an animal, of a being that can be violated, kidnapped, molested and assassinated with impunity. [. . .] We have had it up to here because others of our children, due to the absence of a good government plan, do not have opportunities to educate themselves, to find dignified work and spit out onto the sidelines become possible recruits for organized crime and violence. We have had it up to 
here because the citizenry has lost confidence in its governors, its police, its Army, and is afraid and in pain (Sicilia 2011).

Many capos, cartel bosses, are able to infiltrate the political system by offering bribes and incorporating leaders into the trade in order to protect their business interests. Police have been known to guard airstrips and shipments for smugglers as well as tipping them off about upcoming raids (Paternostro 1995; 44). Mexican cartel leaders are able to lure many individuals into drug trafficking due to inadequate pay and the threat of violence. Most Mexican police officers are underpaid, poorly trained, and inadequately equipped. Sources report that entry and lower-level police officers throughout Mexico earn less than \$250 USD per month. Furthermore, they are outmatched and overpowered by drug trafficking organizations that use extreme measures of violence against them and their families (Schaefer, Bahney, \& Riley 2009; 4). In the face of the threat of death, the courage and ability to remain immune to corruption is extremely low. There is a saying in Mexico that captures the threat of violence: "plomo o plata" ("lead or cash"). However, there are still those who attempt to withstand offers of bribery. By doing so, they accept the risk of possible acts of retribution, including death. For example, in 2008, many high ranking officials were murdered when they refused to involve themselves with cartels (Schaefer, Bahney, \& Riley 2009; 2-3). Again in 2008, the Police Chief of Ciudad Juárez Roberto Orduña Cruz was forced out of office due to threats made by a Mexican drug cartel. They threatened to kill a police officer every forty-eight hours until he resigned; they kept their promise and murdered six before Orduña resigned and fled the city (Lacey 2009).

The same factors that provoke police collusion with cartels are the same ones that entice many others to become complicit in illegal cartel activities. Accounts of narco-trafficking have not only been chronicled by local, national, and international news outlets, but have also been 
captured and reported by a musical newspaper, drug ballads known as narcocorridos. The narcocorrido is a musical composition that is notorious for its violent protagonists and powerful storylines. A new generation of corridistas, [narco] corrido artists and composers, have embraced the violent aspects of the drug trade by transforming a traditional music form into one that has become almost as controversial as drug trafficking itself due to its graphic nature and the assumption that it promotes violence.

This thesis will examine how Mexican drug ballads capture and reflect the presence of narco-culture in society and how the narco-lifestyle is glamourized through their narratives. The analysis will be developed using the model set forth by Charis Kubrin in "Gangstas, Thugs, and Hustlas: Identity and the Code of the Street in Rap Music." Kubrin explores issues of identity, culture, and violence among inner-city youths through an analysis of 403 gangsta rap songs. He examines the role of the street code in rap music and how it influences the way inner-city black youth perceive violence and respect on the street, participate in crime, and identify themselves. Utilizing Kubrin's cultural, literary, and sociological approach to analyze narcocorridos allows the consideration of both the text itself and the conditions of its production and consumption; for this reason, social conditions that perpetuate narco-culture as well as the history of policies, procedures, and laws of Mexican and U.S. entities pertaining to the regulation and interdiction of narcotics will be discussed. People often delineate events in society through cultural narratives and artifacts. Therefore, it is necessary to place Mexican drug ballads in context with social, economic, and political issues in order to begin to see and understand the complex nature of their existence and their ability to express social conflict that often reflect harsh cultural, political, and economic conditions. 
This examination will utilize the street culture framework established by Elijah Anderson. The same aspects that dictate street life as identified by Anderson can be applied to circumstances surrounding the drug trade between Mexico and the United States. He claims that issues of violence in urban areas emerge from circumstances of the ghetto poor - lack of decent paying jobs, race stigmas, drug use, and the illegal sale of drugs. Similar problems that face urban black communities are also present in rural, middle, and low-class areas in Mexico, along the border, and in other Hispanic populated metropolitan areas such as Los Angeles, Miami, New York, Phoenix, and Chicago.

This discourse will also utilize John McDowell's study on the relationship between poetry and violence. McDowell identifies three theoretical approaches in his study on the social functions of corridos from the Costa Chica region of Guerrero, Mexico. The first approach, or the celebratory thesis, refers to the manner in which corridos proliferate violent events and inspire listeners to follow in the protagonist's footsteps. The regulatory thesis maintains that these ballads not only glorify violent deeds but also serve as a means to interpret and understand these events. Lastly, the therapeutic thesis states that while corridos do not and will not heal those dealing with the violent events captured by the musical compositions, they do however, serve as an emotional outlet for these individuals to cope with them. Using Kubrin's study as a template and incorporating Anderson's "code of the street" with McDowell's scholarship on the relationship between poetry and violence allows for a comprehensive examination and understanding of narcocorridos. 


\section{Literature Review: Background of the Narcocorrido - The Romance Español and the Traditional Mexican Corrido}

The romance is a Spanish oral tradition that can be best defined as a lyrical poem that tells a story that emerged during the middle ages. It is believed that the first romances were fragments of longer, epic poems that sang the deeds of great heroes. The singer-poet would travel from town to town reciting these poems to the people in order to make a living. People would memorize and recite their favorite fragments to others, thus transmitting and conserving the romancero español, a collective product of the pueblo, or the people. Due to the fact that the romance is transmitted orally, it contains certain poetic expressions that facilitate memorization, such as: repetition, rhyming, epithets, and dramatic characterization. However, the development and continuation of the ballad was not confined to Spain. Spaniards carried the ballad tradition with them wherever they traveled, including Mexico in the sixteenth century as part of the Spanish conquest of the Americas.

The traditional Mexican corrido evolved from the Spanish romance with which it shares several characteristics, most notably in terms of form and structure. For example, the romance contains an indeterminate number of octo-syllabic lines alternating in pairs with assonant rhyme scheme in the even lines and none in the odd. Similarly, the traditional corrido consists of eight quatrains that contain four to six lines, each of which is usually octo-syllabic (Paredes 1995; 132133). While eight syllables are considered standard for corrido verses, some may have more; the flexibility of the corrido is a unique characteristic of the genre. The corrido began to develop characteristics that made it a Mexican production during the years of the Mexican Revolution (1910-1920). For example, there are five characteristics that most commonly occur in the Mexican corrido that make it a distinct genre from the romance. They are: 1) The corridista's 
initial greeting to the public, 2) the introduction of the protagonist and/or event to be sung by providing the date, location, or name of the protagonist(s), 3) the message or moral of the story, 4) the protagonist's farewell, and 5) the corridista's farewell, or la despedida. Another fundamental difference between the romance and traditional corrido is the musical component of corridos. The Mexican corrido typically employed the use of one or more guitars, but overtime transitioned to the accompaniment of norteño bands (Torres 2013; 112).

During the revolutionary period, ballads delineated the struggles of the Mexican Revolution: from tragic tales to stories of honor and heroism of those who fought on behalf of the poor like Emilio Zapata and Francisco Villa (Chew Sánchez 2006; 34). In the years of the traditional corrido, the protagonists were revolutionaries: heroes who fought for a cause and made sacrifices for their communities. "Corrido de la Muerte de Zapata" performed by Los Hermanos Záizar sings of the revolutionary hero Emiliano Zapata. This corrido highlights the valiant nature of Zapata as a protector of the people: ${ }^{1}$

El gran Emiliano que amaba a los pobres, The great Emiliano that loved the poor, Quiso darles libertad That wanted to give them freedom Por eso los hombres de todos los pueblos This is why all the men from the town Con él fueron a luchar Went with him to fight

He is referred to as "el gran insurrecto" or "el valiente," which is congruent with popular belief regarding Zapata among the Mexican people, even today. During the revolution, Zapata advocated for local peasant farmers in the form of land redistribution and ownership. The ballad ends exalting Zapata's name and his heroic actions that characterize his legacy as a protector of his people, for which he paid the ultimate price:

\footnotetext{
${ }^{1}$ Unless cited otherwise, narcocorrido translations are my own.
} 
Abril de 1919 en la memoria

Quedará del campesino

Como una mancha en la historia

Cual héroe murió Zapata

Por dar tierra y libertad
April of 1919 in the memory

Will remain with the campesino

Like a stain on history

The hero Zapata died

For land and freedom

Corridos were a way to spread news about battles, victories, and defeats of the revolutionaries due to the fact that radio and television did not exist during this period (Mendoza 1939; xiii). Moreover, many people did not know how to read, so written publications failed to reach a large part of the population. In the years following the revolution, corridos told stories of issues other than war, such as: love, prohibition, folk heroes, hometowns and regions, migration, natural disasters, homesickness, and social and political events (Chew Sánchez 2006; $34)$.

In addition to the celebratory, regulatory and therapeutic theses that have been presented, McDowell describes the corrido tradition as a living ballad that he defines as a "ballad in its source community, typically a community that embraces a visionary heroic worldview" (McDowell 2000; 42-43). McDowell examines the effects that poetry about violence has on communities' and people's responses to violence (McDowell 2000; 7). Similarly, Martha Chew Sánchez explores how corridos help shape the identities of recent migrants in her book Corridos in Migrant Memory (2006). Both scholars find that corridos are cultural artifacts that narrate events in society; this means that corridos are transitive and directly reflective of changes in society especially at times of transformation and crisis (Chew Sánchez 2006; 91). As a result of the transitive nature of corridos, composition and dissemination processes began to change 
around the 1930s. Following the revolution, corridos began to be recorded due to the industrialization process. During this time, corrido production remained steady, but no ballads were produced that gained significant notoriety. It was not until the early 1970s that a major hit was produced, which came at a peak period for Mexican drug trafficking and U.S. demands for narcotics such as opium, marijuana, and cocaine.

Narcocorridos, or Mexican drug ballads, are a contemporary form of the corrido that evolved from folk or banda music in the northern part of Mexico and along the border in the United States. The narcocorrido is sometimes compared to gangsta rap due to its exciting allegories of the narcotraficante who rises above his poor, marginalized societal classification to become a powerful and wealthy figure in the drug trade (Ragland 2009; 11). The stories reflected in Mexican drug ballads highlight the lifestyle of drug lords and aspects of the drug trade that are imbued with violence. Narcocorrido lyrics focus on misfortunes and death as part of their narrative structure while referencing events related to illegal criminal activities of the drug trade (Paredes 1995; 133).

While McDowell provides a basis for an analytical study of corridos that can be applied to narcocorridos, Elijah Wald explores the roots of contemporary Mexican drug ballads in his book Narcocorrido: A Journey into the Music of Drugs, Guns, and Guerrillas (2001). Wald delves into the "music of drugs, guns, and guerrillas" by traveling deep into Mexico and to urban centers. In his travels, he visits composers and producers in their homes, conducts interviews, and explores notoriously cartel-controlled areas. In doing so, he immerses himself in the very violent and dangerous culture of drug trafficking. He offers a unique contribution to the study of narcocorridos by providing rare insights through interviews conducted with composers who have transformed the genre into what it is today. Artists and composers interviewed in his book 
give personal testimonies to their views of the cultural phenomenon that the "drug-war" has created, as well as first-hand experiences they have had due to their intimate connections with the drug trade. As a result of the diversity of respondents, separated by space and time, Wald provides a chronological history of the traditional revolutionary corrido to the modern-day drug ballad. 


\section{CHAPTER II \\ HISTORICAL REVIEW}

\section{Mexico: A History of Violence}

Social and political conflicts have plagued Mexico since its origination. These struggles include civil wars, poverty, economic instability, inequality, and exploitation which are rooted in the Spanish Conquest and extend to contemporary Mexico. Through the years, these factors have served as a catalyst to forge inequality and violence in all sectors of the country. Some argue that cultural violence is rooted in the brutality of Mexican history. In his book $A$ New Time for Mexico, Carlos Fuentes equates Mexico's history to a layered cake. He asserts that Mexican chronology can be divided into defining moments and important events which aid in the comprehension of the Mexican nation, all of which involve violence.

On August 13, 1521, forces led by Hernán Cortes conquered Tenochtitlan, the capital of the Aztec empire, present-day Mexico City, an event that resulted in centuries of Spanish rule as well as a history of inequality and violence. The Conquest was a sudden and catastrophic clash of civilizations that ultimately led to the destruction of numerous indigenous groups, as well as their cultural customs and languages. One of the main purposes of the conquest was evangelism; once the Spaniards had enacted military and political control over the newly conquered enclaves, they were able to begin the processes of colonization and Christianization. During the sixteenth and seventeenth centuries, commercial and religious centers were constructed to promote a Christian and mercantile society. This society was a stratified caste system: whites of European origin or descent including Spaniards born in Spain and criollos, people of Spanish ancestory 
born in Mexico, mestizos, and indigenous peoples and Africans. Spaniards born in Spain were superior to all other classes. Mestizos, or individuals of mixed European and Indian lineage occupied the second class. Lastly, indigenous peoples and Africans were widely regarded as inferior in colonial Spanish Mexico (Hassig 1994).

Spanish colonial rule lasted for three centuries until criollos began to seek greater autonomy and social inclusion. This served as a catalyst that sparked the Mexican War of Independence in 1810 when Miguel Hidalgo y Costilla (1753-1811), a criollo priest, led an uprising in the northern state of Guanajuato inciting Indians and mestizo peasants. His small group of Indian and mestizos grew to number over 80,000 . For nearly twelve years, revolutionaries fought against the royalists, who desired to preserve Spanish rule and power of the Catholic Church. The revolutionaries were nearly defeated early on by the royalists; both Hidalgo and José María Morelos, a Catholic priest who assumed leadership of the revolutionary rebels following the execution of Miguel Hidalgo, were captured and executed by a firing squad in 1811 and 1815, respectively. Following their deaths, Vicente Guerrero (1782-1831), a mestizo who had fought under Hidalgo and Morelos, continued the quest for independence. But it was only when Agustín de Iturbide (1783-1824) shifted from the Spanish royalist side and joined with Guerrero's revolutionaries that the tides turned in favor of the revolutionaries. In February of 1821, Iturbide negotiated the Plan de Iguala, also known as the Plan of Three Guarantees, which declared Mexico's independence from Spain and established several articles that provided a governing basis for the Mexican empire. ${ }^{2}$ After three-hundred years of colonial rule and eleven years of brutal bloodshed, Mexico finally achieved independence on September 27, 1821

\footnotetext{
${ }^{2}$ The three main provisions that the Plan de Iguala outlined were independence from Spain, equality for all social and ethnic groups, and the declaration of Catholicism as the nation's religion (Fehrenbach 1995).
} 
(Tannenbaum 1950). However, the independence movement did not meet expectations of unity and equality and the revolutionary coalition failed because the newly independent Mexican government was unable to provide stability and order (Fehrenbach 1995). Iturbide named himself emperor of Mexico, but was unable to govern the country; civil unrest continued, and violence ravaged the nation as Iturbide's supporters began to turn against him. In 1823, the emperor was overthrown by insurgents led by Antonio López de Santa Anna (1794-1876), a general in the Mexican Army who initially opposed the Mexican Independence movement, but later supported it. ${ }^{3}$

In the years following Independence, the Texas Revolution took place. In 1835, American settlers in Texas fought for independence from Mexico because they did not agree with the manner in which they were being governed. A year later, the United States recognized their independence, while Mexico maintained that Texas belonged to them. Tensions grew until 1846, when the United States, under the leadership of President James K. Polk, invaded Mexico, sparking the Mexican - American War (1846-1848). There were several motivations for the invasion, but ultimately the war was a struggle for land. Mexico fought to keep its territorial integrity, while the United States desired to retain the disputed land of Texas and other northern Mexican territories. The war proved to be a disaster for Mexico; it lost every major battle and was subsequently forced to cede more than half of its national territory to the United States as

\footnotetext{
${ }^{3}$ Following Independence, he served as president of the country multiple times. Subsequently, Iturbide fled the country; however, in 1824, unaware of a decree of death placed upon him by congress, he returned to Mexico only to be executed four days later (Bazant 1977; 47-61).
} 
outlined by the Treaty of Guadalupe Hidalgo (1848) which ended the brutal conflict (Bazant $1977 ; 53-61){ }^{4}$

Fueled by the outrage of the Treaty of Guadalupe Hidalgo and the Venta de la Mesilla, or the Gadsden Purchase $(1854)^{5}$, the Revolution of Ayutla $(1854)^{6}$ gave way to a bitter three-year war between liberals and conservatives referred to as La Reforma, a period characterized by liberal reforms. The Reform sought to implement a secular, democratic nation state by dismantling the old conservative, Catholic state. Constituents of this movement believed that modernization was a manner to strengthen the nation and set out to restrict land holdings of the Catholic Church and the upper class. In an effort to limit the Catholic Church's power, the Constitution of 1857 was drafted (Fehrenbach 1995; 403-422). The clergy and conservatives were not in favor of the new constitution and planned a revolt leading to the War of Reform (1857-1861). This period of unrest was followed by an invasion by France in 1861, which placed the nation in yet another war that lasted six years until 1867. At this time, Benito Juárez (1806-1872) took office and remained there until his death in 1872 (Fehrenbach 1995; 423-437).

\footnotetext{
${ }^{4}$ The United States gained the modern-day states of Texas, California, Utah, and Nevada, as well as parts of New Mexico, Arizona, Wyoming, and Colorado through the Treaty of Guadalupe Hidalgo.

5 The Gadsden Purchase was an attempt at alleviating lingering territorial disputes between the two countries following the Mexican - American War (1848). The treaty was signed on June 8, 1854 by U.S. President Franklin Pierce and Mexican President Antonio de Santa Anna in which the United States agreed to pay Mexico ten million dollars for 29,670 square miles of northern Mexican territory (presentday Arizona and New Mexico). It also created the border which still exists between Mexico and the United States (Bazant 1977; 60-61).

${ }^{6}$ The Revolution of Ayutla, named after the Plan of Ayutla, sought to expel Santa Anna and draft a constitution (Fehrenbach 1995; 412).
} 
Following the death of Juárez, Porfirio Díaz (1830-1915) rose to power, initiating a period known as El Porfiriato (1876-1911). During its thirty-four year reign, the Díaz Administration aimed to industrialize Mexico. Dramatic economic improvements were realized through commercialization and capitalist expansion. However, these accomplishments came at the price of democracy. Díaz governed as if the constitution did not exist by rigging elections, controlling the press, and "electing" friends to serve in office. Furthermore, there was a concentration of land power in the hands of the elite and a huge disparity between the rich and poor. The issue of land concentration was compounded by the practice of allowing foreigners to take communal land away from indigenous people, further expanding the gap between the wealthy and the poverty-stricken. The abuses of a dictatorship, exploitation of workers, and great disparity between the rich and poor gave rise to the Mexican Revolution (Fehrenbach 1995; 440-481).

In 1910, the Revolution began as an effort to overthrow Porfirio Díaz led by Francisco Madero (1873-1913), a wealthy Mexican politician. The widespread rebellion eventually changed the structure of Mexico's economy, government, and society, but disparities persisted. After the popular insurrection removed Díaz from power and the counterrevolution that hoped to restore the Porfiriato failed, the revolution became a fight between two factions. Moderate and conservative leaders such as Francisco Madero and Venustiano Carranza (1859-1920) primarily sought political reform, including free and fair elections that would create a new, modernized, national state. Conversely, the two most famous rebel leaders, Francisco "Pancho" Villa (18781923) and Emiliano Zapata (1879-1919), and their constituents supported radical socio-economic reforms in favor of the lower classes, including redistribution of land, limits on the influence of the Catholic Church, and labor reforms that would give workers the right to organize and strike. 
The movement's lack of cohesion prevented it from securing the political transformations it sought. The revolutionary conflict effectively ended in 1921. However, political stabilization under the Álvaro Obregón (1880-1928) and Plutarco Elías Calles (1877-1945) regimes was limited and the agrarian issue, a major cornerstone of the revolution still had not been resolved (Fehrenbach 1995; 482-575) (Hart 1987; 340-347). Elías Calles attempted to establish a modern, secularized state, but it incited the Cristero Rebellion (1926-1929), an armed conflict against the Catholic Church (Meyer 1976). It was also during this time when the Partido Nacional Revolucionario (PNR), National Revolutionary Party, was founded by Plutarco Elías Calles in 1929, the party now known as the Partido Revolucionario Institucional (PRI), or Institutional Revolutionary Party. This marked the beginning of the PRI's political control in Mexico.

During his presidency, Lázaro Cárdenas (1895-1970) sought social and political reforms. Cárdenas had roads and schools constructed, promoted education, sought agrarian reform for peasant communities, and nationalized Mexico's oil industry. Presidents Miguel Ávila Camacho (1897-1955) and Miguel Alemán Valdés (1900-1983) returned to more conservative policies that focused on industrialization, protection of the working class, and land reform while repairing relationships with the United States. Conservative policies employed by these two administrations supported economic growth throughout and during the 1960s. The administrations of Luis Echeverría (1970-1976) and José López Portillo (1976-1982) were marked by governmental spending that ultimately led to the economic crisis of 1982 . Miguel de la Madrid (1934-2012) attempted to combat inflation and high unemployment rates by encouraging investment and decentralizing the nation's economy. However, his presidency is marked by two of the worst earthquakes that Mexico ever experienced that left thousands dead 
and hundreds of thousands homeless. The administration's poor response to these disasters increased resentment toward the PRI.

The PRI retained its political power in the country for seventy-one years and has been criticized for unprecedented corruption at all levels. Beginning in the late 1970s, Mexico experienced a democratic transition, and measures were taken to enhance civil and political rights. In response to massive electoral fraud, the Partido de la Revolución Democrática (PRD), Party of the Democratic Revolution, was established and demanded several political reforms,. Political elections were removed from the direct supervision of the PRI which created a more level playing field and was ultimately the precursor to the fall of the PRI with the victory of President Vicente Fox in the election of 2000. During Fox's time in office, the business of illegal drug trade grew larger and gained political influence by infiltrating weak political regimes and circumventing the rule of law due to political collusion (Purcell and Rubio 2004). The PRI remained out of power yet again when President Felipe Calderón was elected in 2006. Calderón's confrontation against drug trafficking was his response to combat widespread corruption of the PRI. However, the PRI regained control in 2012 when current President Enrique Peña Nieto was elected into office.

\section{Mexico and the United States: The "War on Drugs"}

Two nations and cultures converge along the U.S. - Mexico border creating a rich and diverse border culture with stark contradictions of wealth and poverty. Like most other border regions, this borderland has given rise to distinct forms of commerce, cuisine, music, dance, and art (Ross 1987). The emergence of the corrido tradition along the border is an example of an art form partly created from border culture. Américo Paredes, a Mexican-American scholar, 
attributes the corrido's appearance and subsequent popularity along the U.S. - Mexico border as a result of social struggle, class conflict, and economic exploitation. He directly references the negative impact of the expropriation of the northern third of Mexican national territory as part of the Treaty of Guadalupe Hidalgo $(1848)^{7}$ as an influence on the development of the ballad tradition (Paredes 1958; 94). This border culture also produces many contradictions such as social inequality and economic marginality. Payan captures the "flavor of the border" best by describing it as a "varied tapestry of wealth and poverty, hope and despair, backwardness and progress" (Payan 2006; 4). Maquiladoras are an example of this. In the 1960s, maquiladoras or maquilas originated in Mexico along border in cities such as Ciudad Juárez, Tijuana, and Matamoros. They are assembly plants that produce products such as auto parts, appliances, electronics, furniture, and clothing for export to the United States at extremely low wages. It is estimated that ninety percent of all products produced in maquiladoras are exported to the United States. These factories can be equated to "sweatshops" as most employees are single women who work for as little as fifty cents (USD) an hour for ten hours a day, six days a week (Mungaray 1998).

An important and influential aspect present along the border is the international trade of arms and narcotics between the United States and Mexico. The drug trade is affected by historical, social, political, economic, and geographical factors. Aspects that contribute to its complexity include the border region, how Mexico and the United States individually and jointly

${ }^{7}$ Drafted by U.S. peace commissioner Nicholas P. Trist, the Treaty of Guadalupe Hidalgo effectively ended the Mexican - American War when signed on February 2, 1848, in Mexico. The treaty granted the United States more than 500,000 square miles of northern Mexican territory. In exchange for the acquisition of present-day California, New Mexico, Arizona, and parts of Colorado, Utah, and Nevada, the United States was required to pay a sum of fifteen million dollars in compensation for damage to Mexican property due to the armed conflict (Article XII) (Weber 1973; 162). 
participate in the trade, U.S. consumption patterns, political susceptibility to corruption, violence that accompanies the drug trade, the influence and power of Mexican cartels, and illegal immigration. Both countries have policies geared toward attacking these issues and in recent years many of these efforts have become more militarized. Despite interdiction efforts, drug trafficking continues to dominate many sectors of society and directly challenge governmental authority, especially in Mexico. Furthermore, violence continues to increase as efforts to combat the flow of illegal drugs intensify, especially at the border.

Border relations were not always as acrimonious, nor as violent as they are today. The border region had very few, if any, checkpoints or restrictions regarding persons, goods, and services. The border boundary, as it exists today, was established in 1848 with the Treaty of Guadalupe Hidalgo following the Mexican - American War (1846-1848), then again with the Gadsden Purchase (1854). Animosity still exists in Mexico concerning the area lost through these treaties; many still consider the territory acquired stolen property, which adds to the complexity of U.S. - Mexico relations and more importantly issues, activities, and commerce conducted along and across the border, specifically drug trafficking. It was not until 1908 that the U.S. began logging entrance and exit records (Paredes 1976). A border tax was then required to pass through checkpoints, but if one could not afford it they would simply cross at a location unguarded by agents. Even then, there were no reports of any legal repercussions such as arrest, detainment, or deportation for "illegal" entries (Payan 2006; 7). Changes to the largely open and free border can be attributed to six key moments. The first was in 1910 with the start of the Mexican Revolution. Boundaries began to be constructed in an effort to keep fighting from 
overflowing into the United States. ${ }^{8}$ The second factor was U.S. involvement in World War I (1917-1918). While the war did not directly affect border relations, the U.S. emerged as a world power, which deepened socio-economic disparities along the border. Another factor that began to change the atmosphere of the border was the implementation of the Eighteenth Amendment (1919), ${ }^{9}$ which led to stringent laws that prohibited the "manufacture, sale, or importation of alcoholic beverages and practices to enforce prohibitionist laws" (Payan 2006; 10). Contrabandistas, smugglers, would illegally transport alcohol into the United States during the prohibition years. The fourth dramatic change came with the creation of the U.S. Border Patrol ${ }^{10}$ in 1924. The fifth came with the Nixon Administration's declaration of the "War on Drugs" which involved efforts to impede the growing drug problem in the United States. Lastly, the terrorist attacks of September 11, 2001, prompted immediate measures to secure all U.S. borders and points of entry in the interest of national security (Payan 2006; 13-14). Increased security

${ }^{8}$ In March of 1916, Francisco "Pancho" Villa led a raid of five-hundred men into Columbus, New Mexico. Seventeen Americans were killed in the attack while more than one-hundred of Villa's men were murdered in retaliation. Scholars debate Villa's motives for the attack; three of the most believed reasons are: 1) Villa's disdain of the Wilson administration for its support of Villa's adversary Venustiano Carranza, 2) retaliation against U.S. arms dealers who provided Villa and his supporters faulty weapons that were used in the Battle of Celaya, and 3) an attempt to acquire rations of food and other weaponry. This attack increased hostilities along the border (Katz 1978).

9 The Eighteenth Amendment that prohibited the "manufacture, sale, transport, import, or export of alcoholic beverages" was voted into existence in 1919 and implemented into law the following year.

${ }^{10}$ In 1915, the first official inspectors were charged with patrolling the U.S. - Mexico border by Congress. This group rode around on horseback and was referred to as "Mounted Guards." Today, the United States Border Patrol falls under the Department of Homeland Security and is charged with the "detection and prevention of the illegal entry of aliens and smuggling of illegal contraband into the United States anywhere other than a designated port-of-entry" (U.S. Customs and Border Production). 
measures forced traffickers to find alternative means to transport their products which subsequently increased levels of violence.

The 1970s-1980s were a period when drug trafficking and consumption dramatically increased on both sides of the border. This was fostered by two leading factors: 1) an increase in consumption patterns in the U.S. and 2) the economic crisis of the 1980s in Mexico. The drug trade is driven by demand. As the market for people using illicit drugs such as cocaine, heroin, and marijuana increased, Mexican drug trafficking organizations subsequently grew. Concern regarding substance abuse by the American population grew through the 1960s until Richard Nixon declared the modern-day "War on Drugs." On June 17, 1971, he stated that, “America's public enemy number one in the United States is drug abuse. In order to fight and defeat this enemy, it is necessary to wage a new, all-out offensive" (Nixon 1971). U.S. consumption patterns have continued to increase throughout the years. In 2012, the International Narcotics Control Board (INCB) reported that "North America remains the biggest illicit drug market in the world" (International Narcotics Control Board 2012; 62). America's insatiable appetite for drugs is, in large part, supplied by Mexican sources, and if substances are not produced in Mexico, they likely travel through the country in order to arrive at their northern destinations. As a result, many organizations and task forces have been created to combat drug trafficking via Mexico, beginning in the 1970s with Nixon.

One such agency created was the U.S. Drug Enforcement Administration (DEA). ${ }^{11}$ In addition, several eradication and interdiction operations were launched. One such mission was

\footnotetext{
${ }^{11}$ The Drug Enforcement Administration, whose mission is to enforce the controlled substances laws and regulations of the United States, was created by Nixon through an Executive Order in 1973 ("United States Drug Enforcement Administration").
} 
Operation Intercept (1969) which was implemented to "deter and detect the illegal importation of marijuana" across the United States-Mexico border (Gooberman 1974). Operation Intercept transitioned to a new strategy known as Operation Cooperation (1970). In contrast with this program's predecessor, Operation Cooperation was a less invasive surveillance cohort between Mexican and U.S. law enforcement officials to minimize the economic burden of drug interdiction programs to those individuals who lawfully conduct business and commerce between the United States and Mexico (Ruiz-Cabañas 1992).

Drug policy varied over the next several presidencies. President Jimmy Carter (19771981) pushed for the decriminalization of marijuana while Ronald Reagan's term (1981-1989) was characterized by anti-drug campaigns such as D.A.R.E ${ }^{12}$ as well as extremely high incarceration rates due to increased efforts against drug dealers and users. The drug war continued to escalate through Bill Clinton's Administration (1993-2001) until George W. Bush (2001-2009) took office. This was when the paradigm shifted to a more militarized drug strategy.

Although drug trafficking in Mexico existed in years prior to 1970, the focus here is on drug policies that coincide with Nixon's "War on Drugs" due to the fact that this was at a time when both prevalence and influence of the drug trade increased. The administrations of Luis Echeverría (1970-1976) and José López Portillo (1976-1982) were characterized by political collusion with Mexican drug trafficking organizations under the Partido Revolucionario Institucional (PRI). Drug traffickers relied on the compliance of political leaders in order to conduct business operations. In return for their cooperation, political leaders and other

12 D.A.R.E., which is an acronym for Drug Abuse Resistance Education, was founded in 1983 by Los Angeles Police Chief Daryl Gates with the mission of "Teaching students good decision-making skills to help them lead safe and healthy lives" (D.A.R.E. America). 
government and law enforcement officials would receive payoffs from the cartels. However, following Nixon's "War on Drugs" declaration, the U.S. increased pressure on Mexico to aid in their efforts. Echeverría resisted pressure of U.S. intervention until his final year in office. In 1975, the United States and Mexico came together to combat the threat of drug trafficking at the source. One such joint effort was Operation Condor (1975), an eradication program aimed at destroying crops from the air by using herbicides (Craig 1980).

Miguel de la Madrid (1982-1988) took office when economic hardship befell Mexico and successful U.S. interdiction programs disrupted trafficking operations in countries other than Mexico. The financial crisis occurred in 1982 when the collapse of world oil prices caused a debt crisis. ${ }^{13}$ In an effort to minimize the effects of a failing economy and to regain control over the economy, Mexico began to cooperate with the U.S. in financial and political affairs. In addition to other factors, the economic crisis of the 1980s increased the allure of the drug trade, as it was a way to ease hardships from the failing economy. Moreover, money generated from the drug trade provided many necessary resources such as roads, electricity, and housing; it even aided the economy by providing business opportunities (Barragán 1997; 186). As a result of these converging forces, it was during the 1980's that drug that drug trafficking became a major concern in Mexico. Colombian cartels began partnering with Mexican traffickers following U.S.

\footnotetext{
${ }^{13}$ Mexico adopted an economic policy that was based on state intervention in the economy from the 1930s through the 1980s. Mexican companies were privately owned, but worked in association with the State in order to receive subsidies and were thus protected from foreign competition. Work flourished due to companies' ability to pay higher wages; as a result, the economy grew rapidly. However, as the working class and the number of industries grew, so did the cost to subsidize them. Many industries were unable to keep up with these growing numbers which inhibited their ability to export products. Consequently, the economy began to slow and the debt began to expand dramatically which led to a severe recession (Fehrenback 1995).
} 
interdiction efforts that forced the Colombians to find alternative routes. The Colombians, as well as others, would pay Mexican cartels to transport narcotics through their areas of control en route to the United States (Kellner \& Pipitone 2010; 30). It was not until policies and procedures were successful in reducing the production, processing, and distribution in Colombia, Peru, and Bolivia that Mexico emerged as a major contributor in the production and trafficking of illicit drugs. These two events ultimately gave way to President de la Madrid allowing the U.S. to enter the country and essentially intervene in Mexican drug policy decisions.

In 1985, the murder of DEA Agent Enrique Camarena ordered by cartel leader Miguel Ángel Félix Gallardo sparked an increase in the aggressiveness of U.S. tactics and pressure on the Mexican government. Following Camarena's murder, the role of the military and federal police was increased to fight drug trafficking. De la Madrid proportioned a greater percentage of his defense budget toward combatting cartels and the illegal trade of drugs, and even declared drug trafficking a matter of national security. Prior to de la Madrid's term, traffickers conducted business in a rather mild manner under corrupt political leaders. However, due to an increased effort to stamp out drug trafficking and the deterioration of the political body that once protected trafficker's interests, cartel's tactics and modes of operation became more violent.

The fight against drug trafficking organizations continued to increase with the inauguration of President Carlos Salinas de Gortari (1988-1994). He augmented the budget for anti-drug policies, increased policing efforts against traffickers, implemented numerous legal and institutional reforms such as the National Institute for Combating Drugs (1993), attacked governmental corruption, and helped negotiate agreements between Mexico and the United States such as the North American Free Trade Agreement (NAFTA) (1994) and the Northern Border Defense Force (1990) (Esparza, Ugues Jr., \& Hernandez 2012; 13). As a result of 
Salina's efforts to dismantle the power of Mexican traffickers, these organizations now considered the PRI as a direct threat to business operations. In spite of his aggressive efforts against drug trafficking, claims have been made of his family's close ties to narcotrafficking. ${ }^{14}$ This highlights the complicity of political figures and police forces in the drug trade even as the government was implementing interdiction measures.

President Ernesto Zedillo (1994-2000) continued anti-drug and militarization efforts of the two previous administrations. The High-Contact Level Group (1996) was established in a joint effort of the Zedillo and Clinton Administrations to aid in drug information sharing (Esparza, Ugues, \& Hernandez 2012; 18). A major political change came with the election of Partido Acción Nacional's (National Action Party) candidate Vicente Fox (2000-2006), this marked the end of the PRI's 71 year hegemonic rule in Mexico. As with previous administrations, drug intensification continued through President Fox without any significant changes. The increase in arrests, seizures, and extraditions to the U.S. did not seem to do much except increase traffickers' propensity to violence.

Then, upon entering office in December of 2006, President Felipe Calderón (PAN) (2006-2012) took militarized operations to unprecedented levels. Immediately following his inauguration, Calderón activated the Mexican Army to aid in abating drug trafficking and violence (Grayson 2013; iii). His militarized plan, supported by U.S. counterparts, was modeled after successful efforts in Colombia that sought to interrupt and destroy the growth, processing,

\footnotetext{
${ }^{14}$ His brother, Raúl Salinas, is alleged to have Swiss bank accounts numbering in the high millions under false names, money that has been linked to drug trafficking. Furthermore, he is believed to have been a central figure in the drug trade by bribing officials owing to his political affiliation. Raúl's wife was also detained in Switzerland following a narcotics money-laundering investigation (Day 1998).
} 
and distribution of cocoa leaves and cocaine. Similarly, Calderón's plan focused on the confiscation and destruction of illegal substances, weaponry and ammunition, money, and other instruments used by cartels in their criminal enterprises and operations such as communications equipment, vehicles, and police uniforms (Maldonado Aranda 2013; 60). His initiative included police reform in order to counter rampant corruption. ${ }^{15}$ Consequently, over three-thousand police officers and other political figures were arrested for cartel and criminal connections at the federal, state, and municipal levels, and over one-thousand others faced potential charges or other disciplinary actions. As a result, over 10,000 new officers were hired (Kellner \& Pipitone $2010 ; 36)$.

While these operations were successful in the confiscation of drugs, arms, and the apprehension of many traffickers, they have been scrutinized by many due to alleged human rights violations and the extreme escalation of violence. A Human Rights Watch report stated that "rather than strengthening public security in Mexico, Calderón's 'war' has exacerbated a climate of violence, lawlessness, and fear in many parts of the country" (Human Rights Watch 2011; 5). A little over 2,000 killings were associated with the drug war when Calderón took office. Since his inauguration this rate has increased by $260 \%$ from 2007 to 2010 nearing 35,000 deaths by the end of 2010. This drastic increase is due to his all-out military offensive against the drug cartels (Human Rights Watch 2011; 4). Unfortunately, this figure does not only denote law enforcement and trafficker casualties - thousands of innocent lives have been lost in the crossfire. Notwithstanding instances of human rights violations, Calderón's radicalized approach resulted in the seizure of large quantities of drugs, weapons, and money. Instead of diminishing

\footnotetext{
${ }^{15}$ As a part of Calderón's directive on combating political corruption, new standards were implemented for testing and hiring new officers, and active police officers began to be screened for any criminal involvement through the use of polygraph examinations, financial disclosure statements, and drug testing.
} 
the presence and power of cartels, his "militarization" amplified drug-related violence. Additionally, violence has shifted from altercations between cartels to murders of citizens and politicians, mass killings, decapitations, death by firing squad, and hangings in city centers.

The current President of Mexico, Enrique Peña Nieto, was elected into office in 2012. A whirlwind of speculation surrounded how the President would conduct himself in office, as he is a member of the PRI and many worried that the PRI's corruptive manner of governing the country would return. One highly debated issue was that of drug trafficking because he openly disagreed with the methods that former President Calderón employed. President Peña Nieto made it clear that he would not adhere to the same methods; instead, his goal was to stop drug violence by addressing economic and social problems that fuel it as opposed to attacking drug trafficking organizations head on. Since being elected, he has implemented several institutional changes in security strategy to demonstrate that systematic corruption will not be tolerated. In spite of many new initiatives, murder rates have not significantly diminished and violence still seems to control many parts of the country. However, this administration has led to the capture of several high-level bosses including Mario Ramírez Treviño Morales, the Gulf Cartel leader, "El Mayito," a Sinaloan lieutenant who is suspected of being involved in three hundred and fifty murders, and most recently, Joaquín "El Chapo" Guzmán Loera, leader of the Sinaloan cartel. Following the capture of the world's most wanted drug trafficker, "El Chapo," President Peña Nieto said:

The apprehension of one of the most wanted drug lords at the international level shows the effectiveness of the Mexican state, but in no way should it be a motive to fall into triumphalism. On the contrary, this institutional accomplishment encourages us to move forward, working with passion and energy to demonstrate that yes, it is possible to 
achieve a peaceful Mexico. [...] This detention reaffirms the commitment that the government has to employ all of its abilities in fighting organized crime (Shoichet 2014).

The fight against drug production, trafficking, violence, and corruption is multifaceted and disaccord still remains regarding the best manner to handle it. The business of drug trafficking has been sustained by the economic and political power of traffickers. Many argue that the "War on Drugs" is a failure and too costly, both monetarily and due to the death rate. Drug trafficking has not only been the subject of political scrutiny and public concern, but has been captured by a unique artistic expression - the narcocorrido. 


\section{CHAPTER III}

\section{ANALYSIS OF NARCOCORRIDO NARRATIVES}

\section{Socio-Economic Factors in the Composition and Distribution of Narcocorridos}

Coinciding with an increase in drug trafficking, narcocorridos gained popularity in the 1970's and 1980's with their new, exciting tales of danger and extravagant depictions of the lives of drug traffickers. However, as years have passed, the songs have begun to purport acts of revenge and modes of settling the score with rival drug barons in more violent and gruesome manners, which is congruent with the change in cartels' methods of operations due to more radicalized approaches against drug trafficking and related crime by Mexican and U.S. governments. For example, following former President Felipe Calderón's crackdown on drug traffickers, beheadings, mutilations, and shootouts have become a more prevalent focus or topic in ballads - in part because songs reflect shifting realities. Moreover, this violence has not been reserved for those participating in the drug trade, as was done in the past; ciudadanos, or citizens, and families have become cartel leaders' and traffickers' targets in an effort to gain control and enact power over territories while spreading their influence - all of which has been captured by corridistas.

Due to increasing controversy regarding these musical productions, Mexican and American authorities have pursued the implementation of bans that prohibit narcocorridos from being played on the radio, in bars or other venues where alcohol is served in an attempt to avoid incites of violence and crime. Despite attempts to censure these musical productions, in many areas, the music plays on. Thus, several questions arise as to why narcocorridos are produced and listened to in such great numbers in spite of bans. In contrast with traditional corridos, 
Mexican drug ballads are largely produced for money due to increased popularity and commercialization of the genre. The question remains, why and for whom are they produced? Why does such a huge market exist for them? In short, narcocorridos are narratives about values pertaining to community coherence.

Mark Cameron Edberg conducted a series of interviews with consumers and producers of Mexican drug ballads that reveals who comprises the narcocorrido market. In one of the interviews, a radio executive divided the listening population of the six stations he managed into four socio-economic groupings: A, B, C, D. These groupings closely resemble class stratification as identified by W.E.B. DuBois in his work entitled The Philadelphia Negro, a sociological study of socio-economic conditions of black Americans in the Philadelphia area to discern reasons as to why African Americans were not fully integrated into mainstream society (DuBois 1899). DuBois categorized the black community into four classes. The first faction was composed of upper-class individuals followed by hardworking, blue collar laborers who lived comfortably. He referred to the third class as the "worthy poor," individuals who worked hard at providing necessities for their families, but had significant difficulty doing so. Lastly, the fourth group was the "submerged tenth," those who lived beneath the poverty line. This group was more inclined to participate in unlawful activities in order to survive and/or provide for themselves and their families. He found that underlying circumstances of social exclusion, lack of education, discrimination and bigotry, hopelessness, and white supremacy impeded their ability to gain lawful employment and therefore promoted their involvement in illegal activities. DuBois' class characterization coincides with that of the music executive interviewed in Edberg's study. The radio manager revealed that the station that primarily played norteño and banda music such as corridos and narcocorridos had the largest following of listeners who were 
members of the working and lower classes, such as those who work in maquiladoras and participate in the trafficking of illicit drugs.

However, narcocorridos are not solely consumed via the radio, even less than before due to radio bans; they are largely listened to in the street, bars, festivals, and in homes by low, rural class individuals who live near the border, are recent migrants, or who have strong social and familial ties on both sides of the border. It must be noted that narcocorridos are not exclusively listened to by the lower classes. In fact, a percentage of their audience includes the upper class due to the commercialization of the genre: individuals who are educated, politically and socially active, and who do not have close ties in Mexico or participate in illegal drug trafficking activities. Those who support radio bans contend that narcocorridos only promote violence and negatively affect young people who listen to their harsh and vulgar lyrics. In 2001, a "voluntary" ban on the broadcast of drug ballads was implemented in Sinaloa. That same year, Senator Yolanda González Hernández (PRI) from Coahuila argued that the criminal lifestyle is promoted through such ballads and pushed for a national radio ban. She did not wish to infringe upon the constitutional rights of ciudadanos by stating that she did not endorse restricting the production and dissemination of narcocorridos; she simply did not want them to be broadcast on the radio. In her push for a national ban, Senator Hernández cited success at the state level (Wald). For example, narcocorridos were entirely eliminated on airwaves in Nuevo León and Guanajuato while other states were pushing for similar restrictions (Gray \& Johnson, 2013; 510). Representative Elida Bautista Castañón (PAN), also from Coahuila, supported bans in saying, "it is known that man tends to imitate what he sees and hears, so it is logical that a person will act violently if all day long he is seeing scenes of crimes and listening to the adventures of a drug trafficker whose aim is to illegally enrich himself" (Wald). Interestingly, some corridistas 
support this type of censorship as well. In 2002, the lead singer of Los Tucanes de Tijuana, Mario Quintero said, "They [narcocorridos] have fallen into vulgar language. There are fictitious corridos, without a foundation, obscene, vulgar and invented. They sell because they are common. So it's good that they [the authorities] are getting involved in the affair" (Wald). Others contend that radio bans are a violation of their constitutional rights to the freedom of expression, but many state representatives support narcocorrido regulation whether it is in the form of bans or rating them as is done with movies and television shows.

In 1972, Los Tigres del Norte released the song "Contrabando y traición” ("Smuggling and Betrayal"), which sparked the beginning of the genre now known as narcocorridos. This narcocorrido was composed by Ángel González, who is widely known as the "Father of the Narcocorrido" (Burgos Dávila 2011; 105). ${ }^{16}$ It tells the story of a couple, Emilio Varela and Camelia, who cross the border from Tijuana into the United States with their tires stuffed full of marijuana:

16 "Contrabando y traición" was the only narcocorrido Ángel González ever wrote. He still claims to be unsure of how he is considered to be the father of the genre. González claims that the idea for the song was an invention and has no evidentiary value supported by an actual event. Although he agrees that smugglers must have attempted to smuggle dope in tires, he contends that this is the only song that does not have a message or significance in comparison to his other musical compositions. In an interview with Elijah Wald, González said:

That song, I wrote it without thinking, I had no idea what would happen afterward. After my corrido, along came that whole pile of songs about drug traffickers, but I wrote it without any idea of that. It was a problem which I brought to light, but not something I knew much about. I hadn't seen any smugglers or anything. This traffic is something that was, is, and is going to continue being a problem on all the borders of the world, that's how it is, but I never, never ever, though that the song would make it big. Because my songs are something else, they are songs with a message, things from people's daily lives, and those songs aren't (Wald 2011; 20). 
Salieron de San Ysidro, procedentes de Tijuana,

Traían las llantas del carro repletas de hierba mala,

Eran Emilio Varela y Camelia la tejana
They left San Ysidro, coming from Tijuana,

They had their car tires stuffed full of "bad grass" [marijuana],

They were Emilio Varela and Camelia the Texan

When the lovers get to the border crossing they are stopped and questioned by immigration officers, but proceed without any problems with their load to Los Angeles. After they make the exchange and receive payment for the drugs, Emilio informs Camelia that he is moving on to San Francisco where "la dueña de mi vida" is waiting. Camelia is outraged by this and as the song goes:

Sonaron siete balazos, Camelia a Emilio mataba,

La policía solo hallo una pistola tirada,

Del dinero y de Camelia nunca más se supo nada
Seven shots rang out, Camelia killed Emilio,

The police only found the discarded pistol,

Of the money and Camelia not more was ever known

A woman killing her partner and fleeing with the money in a tale of border smuggling was unheard of at this time. The novelty of the storyline, the ostentatious appearance and accordion sound of the members of Los Tigres, along with the peak of the drug trafficking business and public demand for risky accounts of drug smuggling led to the development of today's narcocorrido (Wald 2001; 12). 


\section{Representation of Drug Traffickers, Their Attitudes toward Crime and Death, and the Code of the Street in Narcocorrido Narratives}

Protagonists of narcocorridos are revered as "Robin Hoods," stealing from the rich to provide for the impoverished, overlooked, subaltern groups of society (Berry 2012). An example of this is Jesús Malverde, or Jesús Juárez Mazo, a Sinaloan folklore hero. ${ }^{17}$ His existence has never been verified, but according to various legends he was a bandit killed by authorities in 1909. He is also referred to as the "Bandido generoso" ("Generous Bandit") and "Angel of the Poor" (Wald 2001; 61). Chalino Sánchez sings about this social bandit in "El bandido generoso" $(2004) .^{18}$

Fusilaron en la sierra al bandido generoso

Murió amarrado de un pino con un pañuelo en los ojos

El gobierno lo mató porque era muy peligroso

En Durango y Sinaloa donde seguido robaba
They executed the generous bandit in the Sierra

He died tied to a pine tree and with a scarf over his eyes

The government killed him for he was very dangerous

He used to steal in Durango and Sinaloa

${ }^{17}$ Jesús Malverde has transformed into one of the patron saints for Mexican drug traffickers, adding a religious realm to narcocultura. A shrine has been constructed in his honor in Culiacán, Sinaloa. It is a common misconception that the only ones to worship the narcosaint are participants in the drug trade. In actuality, narcos only make up part of their constituency; believers from all walks of life and socioeconomic statuses travel from all over Mexico and parts of the United States to ask for miracles, his protection, or to give praise for favors already granted (Wald 2001; 60-67).

${ }^{18}$ Born and raised in Mexico, Rosalino "Chalino" Sánchez is one of the most famous corrido composers to date. He defined the genre and had a very distinct style and sound. Sánchez is believed to have been murdered execution style following a 1992 performance in Culiacán, Sinaloa, Mexico by la policía federal, federal police forces in Mexico. His body, found the following morning by two campesinos, was blindfolded with ligature marks on his wrists from being bound. Chalino's death elevated him to a legendary status (Wald 2001; 69-76). 
Para ayudar a los pobres o al que lo necesitaba

Después hacía lo que el tigre al cerro se remontaba

Cuarenta y ocho soldados que

andaban tras de sus pasos

Todos le gritan aun tiempo - ¡Sube las manos en alto

Y no trates de escaparte porque te hacemos pedazos!

Le preguntaba el teniente por que iba robando

- No robo porque me guste tampoco me estoy rajando

Me duele ver inocentes que de hambre andan llorando

- No quisiera fusilarte por tu valor y nobleza

Pero en toditos los bancos tienen precio tu cabeza

- No se preocupe, teniente, cobre usted la recompensa

- Vas a pagar con la vida tu buena acción con la gente

- Eso yo ya lo sabía y no me asusta la muerte

En el infierno nos vemos, allá le espero, teniente
To help the poor or whoever was in need

Afterwards, like a tiger, he would withdraw to the Mountains

The forty-eight soldiers searching for him

All shouted together, "Hands up

And don't try to escape or we have to kill you!"

The lieutenant asked him why he stole

'I don't steal because I enjoy it or like to brag

It hurts me to see innocents crying of hunger"

"I don't like to execute you for you're courageous and noble

But all the banks have put a price on your head"

"Don't worry lieutenent, redeem your reward"

"You're paying with your life for the good you've done for the people"

"That's what I expected, but death doesn't scare me

We shall meet again in hell, there I'll be waiting for you, lieutentant"

(Simonett 204; 2001) 
The "Robin Hood" archetype can be accredited to social, political, and economic conditions present in Mexico. Although drug traffickers commit murder and steal, they do so from the enemy, not their own people. Many cartel leaders are fair and help their people; in this respect, they do more than the government, which is generally characterized as corrupt and more violent than their narco counterparts. Narcos are viewed as powerful figures who ensure the welfare of those in their communities and increase their quality of life by providing basic necessities such as constructing houses and schools, building roads, and providing electricity and business opportunities. The aforementioned amenities may be afforded to the public by the government, but are done so at subpar standards (Edberg 2004; 83-86). Following the capture of one of the most wanted men and drug kingpins in the world, thousands of people flooded the streets of Mexico demanding the release of Joaquín "El Chapo" Guzmán, the head of the Sinaloa Cartel. Several supporters referenced economic opportunities Guzmán created and the protection he afforded citizens. For example, Pedro Ramirez said, "We support 'Chapo' Guzmán because he is the one who gives us jobs and helps out in the mountains" (Caldwell, Spagat, Billeaud \& Weissenstein 2014). Others were quoted saying that his presence in Sinaloa deterred rival cartel factions from victimizing members of the community (Hastings 2014).

The narcocorrido "El niño de la Tuna" ("The Boy from La Tuna") (2009) by Roberto Tapia sings of "El Chapo" Guzmán. He was born in La Tuna de Badiraguato, Sinaloa, to a poor family:

De niño vendió naranjas allá por la Sierra

No más pa' poder comer

Nunca se avergüenza de eso

Al contrario lo dice que fue un orgullo pa'él
As a child he sold oranges in the Sierra

There was nothing more to eat

He was never embarrassed by this

On the contrary, he said he was proud of it 
Guzmán's father was involved in the drug trade as well as others from his hometown. He followed their examples and began working in the marijuana fields:

$\begin{array}{ll}\text { Él forma parte del cartel } & \text { He formed part of the cartel } \\ \text { Más fuerte que existe } & \text { The most powerful around } \\ \text { Es de puro Culiacán } & \text { Purely Culiacán } \\ \text { Traí la camisa bien puesta orgulloso lo dice } & \begin{array}{l}\text { He wore the well-put shirt and proudly } \\ \text { said }\end{array} \\ \text { Yo soy el Chapo Guzmán } & \text { I am Chapo Guzmán }\end{array}$

Through his involvement in the drug trade he became a very powerful figure in the realm of drug trafficking and in society. In Enigma Norteño's ballad "Generales de batalla" ("Generals of Battle") (2012), Guzmán is even compared to Francisco "Pancho" Villa, the famous Mexican Revolutionary General:

Aqui vengo por el pueblo a luchar

Soy el Joaquín Guzmán, El Chapo, El General

Me han comparado hasta con Francisco Villa

Porque al frente siempre traigo mi cuadrilla

Porque estoy en pie de guerra

Y defiendo mi bandera con lealtad

Ahora yo soy dueño del triangulo de oro

En su tiempo Pancho era el mero mero

En mis tiempos yo soy comandante en jefe
I came to fight for the pueblo

I am Joaquín Guzmán, "El Chapo," the General

They have compared me to Francisco Villa

Because I always bring my gang

Because I am on the warpath

And I defend my flag with loyalty

Now I am the master of the Golden Triangle (Chihuahaua, Durango, and Sinaloa)

Pancho was the head honcho in his time In my time, I am commander 
Similarly, Los Tucanes de Tijuana reference the ability for one to transcend their social class through their involvement in the drug trade in "Mis tres animales" ("My Three Animals") (1995). The protagonist in this narcocorrido is a drug baron who came from a lower-class family. It was not until he entered into the drug trade by selling his "three animals" (the parakeet [cocaine], the rooster [marijuana], and the goat [heroin]) that he was able to escape the restraints of poverty and become a wealthy individual (Wald 2001; 28): ${ }^{20}$

$\begin{array}{ll}\text { Aprendí a vivir la vida } & \text { I learned to live life } \\ \text { Hasta que tuve dinero } & \text { Until I had money } \\ \text { Y no niego que fui pobre } & \text { I don't deny that I was poor } \\ \text { Tampoco que fui burrero } & \text { And that I was a mule skinner } \\ \text { Ahora soy un gran señor, } & \text { Now I am a great gentleman } \\ \text { Mis mascotas codician los hueros } & \text { The gringos covet my pets }\end{array}$

(Edberg 2004; 56-57)

These three narcocorridos represent an integral aspect in the emergence and influence of a "street code" in society. Each ballad references poor economic conditions; whether in " $E l$ bandido generoso" in which the protagonist is ultimately murdered as a result of trying to aid the poor or in "El niño de la Tuna" and "Mis tres animals" in which the protagonists hail from poor socio-economic backgrounds. Kubrin states that the "continual demand for economic and social success, coupled with limited legitimate avenues and numerous illegitimate avenues by which to attain it, creates a unique situation" (Kubrin 2005; 362). Poverty limits many individuals from

\footnotetext{
${ }^{20}$ Through Wald's interviews it was revealed that the parakeet, rooster, and goat represent cocaine, marijuana, and heroin respectively (Wald 2001; 28).
} 
achieving social status due to the lack of legitimate opportunities. However, drug trafficking is a means to earn an income that is widely accessible in Mexico.

Material wealth is another aspect highlighted by the code of the street. This is due to its ability to establish self-image and gain respect among their peers. Narcos are able to make something of themselves through illegal and violent operations of the drug trade. They are considered to have everything: money, women, and cars (Wald 2001; 113). Kubrin asserts that ostentatious showings of wealth not only reflect style and image, but more importantly demonstrate the willingness to show off expensive items that may attract attention from wouldbe aggressors; a sentiment present in "El Americano" ("The American") (2012) by Jorge Santa Cruz y Su Quinto Elemento (Kubrin 2005; 364). The protagonist is a Mexican-American male who changed his life by entering into the drug trade in his twenties. Over the years, he committed murder, stole, and even faced danger and death himself. However, his dangerous exploits proportioned him many luxuries:

Me gusta apostar en juegos de baraja

Vestir a la moda con ropa italiana

Autos deportivos y escuchar la banda

Recorrer las calles de Guadalajara
I like to bet on card games

Dress fashionably with Italian clothing

Sports cars and to listen to banda

Run the streets of Guadalajara

Materialistic gains are also the topic in "Estilo Italiano" ("Italian Style”) (2011) by Jesús Ojeda y Sus Parientes:

Vestido a la moda

Y muy elegante siempre anda el muchacho,

Con ropa Burberry le gusta vestir
Fashionably dressed

And always a very stylish boy

He likes to dress in Burberry clothing 
Materialistic showings of wealth do not maintain identity and respect; they must be reinforced by violence, which is a central motif in all narcocorridos. It is also one of the most defining factors in achieving and maintaining respect in the code of the street. Narcos are often faced with aggressive retaliation and opposition from rival cartels or law enforcement that usually results in death, but violent encounters are essential in the preservation of one's image. Dinastia Norteña expresses the urge that many narcos have in committing acts of violence and revenge against others in "La venganza del M1" ("Revenge of the M1") (2010):

$\begin{array}{ll}\text { Es mi vicio la sangre enemiga } & \text { My vice is the enemy's blood } \\ \text { La venganza se me hizo un placer } & \text { Revenge is pleasurable to me } \\ \text { Ahora torturas habrá un infierno } & \text { Now tortures will have a hell } \\ \text { Soy sanguinario a más no poder } & \text { I could not be any more blood thirsty } \\ \text { Me da risa mirarlos tirados } & \text { I laugh looking at them shot } \\ \text { Yla tierra queriendo morder } & \text { And land wanting to bite } \\ & \\ \text { Con un pie presionaba su pecho } & \text { With a foot I stepped on your chest } \\ \text { Con una mano le agarré el pelo } & \text { With a hand a grabbed ahold of your } \\ & \text { hair }\end{array}$

The protagonist takes pleasure in murdering his opposition; but in the last verse, the audience is urged not to kill anyone who has not done them wrong:

$\begin{array}{ll}\text { Ya no maten a gente inocente } & \text { Don't kill innocent people } \\ \text { El que paga aqui es el que la debe } & \text { What is done here, is paid here } \\ \text { Los terceros no tienen la culpa } & \text { Third parties are not to blame }\end{array}$


Hay que hacer frente con los deberes

Los grandes siempre contra los grandes

Ya me voy, me despido de ustedes
Duties must be addressed

The big guys against the big guys

I'm leaving, I bid you adieu

"Las torturas" ("The Tortures") (2011) by Dueto Luis y Ramón depicts a protagonist who has committed many murders throughout his life. The protagonist attempts to recount all of his murders in an effort to determine in which instance he was the most bloodthirsty:

Me quedé pensando un rato

De todos aquellos

Los que he matado

Para ver cuál de esas muertes

He sido más sanguinario

Pues ya son bastantes

Las que me he aventado
I thought for awhile

Of all of those

Who I have killed

To see which of those deaths

I have been the most bloodthirsty

There are quite a few

That I have thrown

The protagonist recounts several of his killings throughout the narrative. For example, he once hung a man from his arm and then began shooting the man to obtain information. In a different murder, the protagonist buried a victim alive who attempted to kill him but the protagonist reacted quicker and killed the aggressor first. By the end of the ballad, the protagonist shows no remorse for the murders he committed and goes on to say that he will continue to torture and kill because he is the most bloodthirsty:

Voy a seguir torturando

No se anden atravesando
I will continue to torture

Do not cross me 

Yo soy de las " $M$ "
I am from the "M"
El más sanginario
The most bloodthirsty

Death is also represented as an inevitable event in narcocorridos, simultaneously reflecting its role in Mexican culture. Death is celebrated in a unique manner in Mexico; funeral ceremonies are festive in comparison to the somberness of North American traditions. Festivals such as Día de los muertos (Day of the Dead) in which the deceased are remembered, honored, and celebrated and images of La calavera catrina (Skeleton Dame) ${ }^{21}$ or La santa muerte (Saint Death $)^{22}$ are held in high regard by the Mexican people. In Mexico, death is not something to be feared as it is part of the inevitable cycle of life. Moreover, death is viewed as an equalizer. Great disparities between rich and poor exist and death comes to all regardless of their socioeconomic status. Many drug traffickers embrace the proximity to death in their attempts to escape poverty. For example, despite the riches that the drug trade has afforded the protagonist in "Mis tres animales," he is aware of the danger that he faces daily from rival traffickers or the government:

$\begin{array}{ll}\text { Traigo cerquita la muerte } & \text { Death is always near me } \\ \text { Pero no se me rajar } & \text { But I don't know how to give in } \\ \text { Sé que me busca el gobierno } & \text { I know the government hunts me }\end{array}$

\footnotetext{
${ }^{21}$ La calavera catrina was an image originally created by José Guadalupe Posada, but gained popularity through Diego Rivera's work Sueño de una tarde dominical en la Alameda Central. It has transformed into a cultural symbol of the image of Death in Mexico and is popular during celebrations of Día de los muertos.
}

${ }^{22}$ La santa muerte is the patron saint of death. She is generally associated with the Mexican celebration Día de los muertos, but is also a saint highly revered by those involved in the drug trade (Barranco 2005). 
Hasta debajo del mar

Pero para todo hay maña

Mi escondite no han podido hallar
Even under the sea

But there is a way around everything

And my hiding place hasn't been found

(Edberg 2004; 56-57)

Death is celebrated in Jenni Rivera's song "Cuando muere una dama" ("When a Woman Dies") (2006). The theme of this narcocorrido is the anticipation of death. The protagonist is asking her friends and family to celebrate her life, instead of mourning her death when the time comes:

Quiero una última parranda

Por allá en mi funeral

Todos los que me quisieron

La tendrán que celebrar

Recordando mi sonrisa

Y mi forma de llorar

Tomen tequila y cerveza

Que toquen fuerte las bandas

Suelten por mi mariposas

Apláudanme con sus palmas

Porque asi es como celebran

Cuando se muere una dama
I want one last party

Over there, at my funeral

All who loved me

Will have to celebrate it

Remembering my smile

And the way I cried

Drink tequila and beer

Let the bands play hard

Release butterflies for me

Applaud me with your palms

Because that is how you celebrate

When a woman dies

“Cara a la muerte" ("Facing Death") (2011) is a narcocorrido performed by Gerardo Ortiz that sings of an unknown drug trafficker's murder from the perspective of the drug trafficker experiencing death himself. The protagonist conducted business with the "enemy," or 
a rival drug cartel. When his bosses discovered his betrayal, they ordered the protagonist's murder for the crime, which the protagonist expected:

\begin{tabular}{|c|c|}
\hline Era esperado & It was expected \\
\hline Que me arrimaran un golpe & That they would put a hit out on me \\
\hline Cuando hay errores & When there are mistakes \\
\hline Hay correcciones & There are corrections \\
\hline Y le falle a los señores & And I let down my bosses \\
\hline Hice negocios & I conducted business \\
\hline Con los contrarios & With the enemies \\
\hline
\end{tabular}

This narcocorrido does not reflect or represent the widely presumed openness toward death. Instead, when death arrives, the protagonist thinks of his family and wishes he could change the outcome:

Quisiera escaper de mi cuerpo

Renacer, tener vida de nuevo
I would like to run away from my body

To be reborn, to have life again

But death is inevitable, and once it arrives, it is almost impossible to evade:

Con la fuerza paraba las balas

El impacto dio una alta descarga

No hubo tiempo de hacer el intento

Sin piedad perforaban mi cuerpo

Con mis manos tapaba mis sesos

y la sangre corría entre mi cuerpo
With my force I stopped the bullets

The impact had a big discharge

There wasn't time to even try

Without piety, they riddled my body

Using my hands I covered my head

And the blood flowed from inside my

body 
Ya lo rojo en lo blanco vestía, era la

Despedida, no tenía salida

Todo era blanco

Agonizaba en mi llanto

Solo en minutos

Se aproximaba

Era el eterno descanso

Muerte en la escena

Luz de sirenas

Los agresores tomaron vereda

En segundos tocaban mi vida

Y el espacio quedo en mi familia

Solo balas y un hombre tirado

Y en su cara un lienzo empapado

Era el afectado
White turned red, it was

Goodbye, there was no escape

Everything was white

Agonizing in my crying

In minutes

It got closer

Eternal rest

Dead on arrival

Siren lights

The aggressors took pathways

In seconds, they took my life

And the space stayed in my family

Just bullets and a hurled man

Over his face, a sodden linen

He was the affected

The previous examples of narcocorridos illustrate how Anderson's code of the street is present throughout the narratives of Mexican drug ballads. A street code emerges when issues of poverty, social exclusion, weak governmental institutions, the lack of legitimate socio-economic opportunities, and the presence of a lucrative, illegitimate options combine in a given area. In Mexico, a narcocultura has emerged that "shapes and constrains residents' behaviors, particularly with respect to violence" (Kubrin 2005; 365). This means that an alternative social order has developed throughout parts of Mexico and the United States that dictates people's 
actions and perceptions. As such, narcocorrido lyrics present narratives that reproduce, represent, and describe activities of individuals involved in the drug trade.

\section{The Representation of Women in Narcocorridos}

It is imperative to discuss Camelia, the protagonist of "Contrabando y traición," when considering feminine depictions and roles in narcocorridos since her role in that particular ballad contributed to the popularity of the genre. As a result of the unprecedented success of "Contrabando y traición," the character of Camelia has been reproduced in several other narcocorridos. Los Tigres del Norte recorded two other ballads with Camelia as a main protagonist - "Ya encontraron a Camelia" ("They Found Camelia") (1975) and "El hijo de Camelia" (“Camelia’s Son”) (1977) (Ramírez-Pimienta 2010-2011; 332). Camelia is represented as a powerful woman involved in the drug trade in "Contrabando y traición" who kills her partner following his betrayal. In "Ya encontraron a Camelia" she is being pursued by la banda, most likely the gang that Emilio Varela was associated with:

La banda la perseguía

En la unión americana

También mandaron su gente

a buscarla hasta Tijuana

Sólo Díos podría salvar

a Camelia, la Tejana

La banda sin detenerse

Para Jalisco volaron

La buscaron en cantinas

Hasta que se la encontraron
The gang pursued her

In the American Union

They also sent their people

To search for her to Tijuana

Only God could save

Camelia, the Texan

Without stopping, the gang

Flew to Jalisco

They searched for her in bars

Until they found her 
Camelia, estás sentenciada

y de ahi se la llevaron
Camelia, you're sentenced

and from there they took her away

In addition to the continuation of the original plot in this narcocorrido, it is narrated from the perspective of the woman that was waiting for Emilio in San Francisco in "Contrabando y traición":

Yo conocí bien a Emilio

Al que Camelia matara

En un callejón oscuro

Yo sin Emilio Varela

Para qué quiero esta vida
I knew Emilio well

The one that Camelia killed

In a dark alley

Me without EmilioVarela

For what do I want this life

Like most narcocorridos, this one ends in death. Camelia is captured and killed by the gang of men searching for her:

Se oyeron varios balazos

Camelia cayó enseguida

Ahora ya está descansando

Con el amor de su vida
Several shots were heard

Camelia immediately fell

Now she is resting

With the love of her life

"Ya encontraron a Camelia" concludes with a warning which is characteristic of narcocorridos:

La traición y el contrabando

Terminan con muchas vidas
Betrayal and smuggling

Ends with many lives

McDowell identifies this type of warning as the "essential paradox" of ballads because the protagonists are celebrated, but also warned of imminent death at the same time (McDowell 
2000; 5). Many individuals involved in the narco-lifestyle remain dedicated to it until they are either imprisoned or meet death, as occurres in "Ya econtraron a Camelia" (McDowell 2000; 101). The storyline is further developed in "El hijo de Camelia" in which Camelia's son seeks revenge for her murder:

\section{Buscando a los delincuentes,} Compañeros de Varela

Sigue vengando a su madre,

Su madre fue Camelia
Searching for the criminals, Friends of Varela He continues to avenge his mother, His mother was Camelia

He travels from Tijuana in search for the men. When he finds them, he murders them. It is said that he is seen in all parts of the country as he continues the hunt for the other men responsible for the death of his mother. In the code of the street, seeking vengeance for this type of crime is considered an appropriate response because it is pursuant of justice. Being involved in a similar street culture as Anderson has identified, Camelia's son feels that the responsibility rests with him to seek justice for his mother's murder. This reveals an important component of the street code: the absence of an effective police force. Anderson states that violent forms of social control are related to law enforcements' abilities to protect and serve its citizens. When police forces are ineffective or completely absent from society an alternative means of social control will arise, which is what can be inferred from Camelia's son's actions (Anderson 1999; $66)$.

Camelia remains the most popular female protagonist of narcocorridos. Corridistas and groups other than Los Tigres have placed Camelia as the central figure in many other drug ballads. Her character has also inspired other storylines in which a woman kills her partner. For example, Juan Carlos Ramírez-Pimienta identifies several narcocorridos with similar storylines 
in his article "Sicarias, buchonas y jefas: perfiles de la mujer en el narcocorrido;" ballads including, but not limited to "La gringuita traficante" (1983) by Mario Rodríguez de Hoyos, "La Venus de Oro" (2000) by Los Huracanes del Norte, "Margarita la de Tijuana" (1977) by Los Tigres del Norte. (Ramírez-Pimienta 2010-2011; 333). However, most drug ballads depict women as strong individuals who do not rely on men when conducting their illegal business adventures. For example, Jenni Rivera's ballad "También las mujeres pueden" ("Women Can Too") (2001) tells the story of five women traffickers who were waiting for a shipment to arrive from Colombia when the police arrived and killed three of women. The women are described as beautiful, but when angered can become extremely violent:

$\begin{array}{ll}\begin{array}{l}\text { Cuando se enojan son fieras } \\ \text { Esas caritas hermosas }\end{array} & \begin{array}{l}\text { When they become angry they are } \\ \text { beasts }\end{array} \\ \text { Those beautiful faces } \\ \text { Y con pistola en la mano } & \text { And with a pistol in hand } \\ \text { Se vuelven repeligrosas } & \text { They become dangerous }\end{array}$

After the three Colombian women are killed by the police, the other two return to la Tierra Blanca. As the narcocorrido comes to a close, women traffickers are equated to their male counterparts in their awareness of danger. When they die, they do so like men:

$\begin{array}{ll}\text { Como los hombres morimos } & \text { We die like men } \\ \text { Esto nunca hay que dudarlo } & \text { This must never be doubted }\end{array}$

One of the most famous narcocorridos involving a woman is "Reina del sur" ("Queen of the South") (2002) by Los Tigres del Norte. Teresa, la mexicana, is the protagonist of the ballad. 
She is introduced as a famous trafficker from the narco state of Sinaloa who fled to Europe following an attack in Ciudad Juarez, a border town. She quickly began trafficking drugs between two continents as the song states:

$\begin{array}{ll}\text { Teresa es muy arriesgada } & \text { Teresa is very bold } \\ \text { Le vende la droga a Francia } & \text { She sells drugs in France } \\ \text { Africa y también a Italia } & \text { Africa, and also Italy } \\ \text { Hasta los rusos le compran } & \text { Even the Russians buy them }\end{array}$

She is described as assimilating quickly upon arrival in Spain by adapting her manner of speech to what is customary there. Teresa is a strong woman that demonstrates her valiant nature in all aspects of her life. Although she resides in Spain, she maintains her Mexican roots through her style:

$\begin{array}{ll}\text { Teresa la mexicana } & \text { Teresa, the Mexican } \\ \text { A veces de piel vestia } & \text { She sometimes wore leather } \\ \text { De su tierra se acordaba } & \text { Which reminded her of her homeland } \\ \text { Con bota de cocodrilo y } & \text { With croccodile boots and } \\ \text { Avestruz la chamarra } & \text { An ostrich jacket } \\ \text { Usaba cinto piteado } & \text { She wore a belt piteado } \\ \text { Tequila cuando brindaba } & \text { Tequila when she drank }\end{array}$

The ballad concludes without knowing what happened to la reina del Sur:

Un día desapareció

Teresa la mexicana

Dicen que está in la prisión
One day she disappeared

Teresa, the Mexican

Some say she is in prision 
Otros que vive en Italia

En California o Miami

De la unión americana
While others say she lives in Italy

California or Miami

In the United States

"La maestra del contrabando" ("The Master of Smuggling") (2002) by Jenni Rivera is a narcocorrido that explains the circumstances as to why a female protagonist entered into the drug trade. Rivera cites hunger and poverty as the two motivating factors which later serve as the justification for her involvement in drug trafficking:

Ya descubrieron que soy una dama traficante

Que entró al negocio prohibido para salir

Adelante y todo porque sus hijos se estaban

Muriendo de hambre
They discovered that I am a woman trafficker

Who entered the prohibited business to

Succeed and because her children were

Dying of hunger

The protagonist says that nobody cares when you are dying of hunger, but society judges and despises you when fail to walk the straight and narrow path. It is clear that the woman is committed to drug trafficking and the code of the street because it is stated that she received her education in "Ciencias del contrabando," or in the "Science of Smuggling," and that the authorities search for her, but are unable to locate and apprehend her:

Me busca la DEA y también la judicial

Dicen que soy la maestra

No me han podido agarrar
The DEA and police search for me

They say that I am the master

They haven't been able to catch me

Most narcocorridos pertain to masculine topics and showcases of bravado. However, women are not entirely excluded, as can be seen through these narratives. It is interesting to see 
that the same factors that influence male involvement in drug trafficking are also the ones that women cite as their motivation to partake in the drug trade. Issues of poverty are the most commonly referenced reasons behind involvement in drug trafficking. The protagonist of " $\mathrm{La}$ maestra del contrabando" explicitly refers to the plight of her children as opposed to her own hunger and poverty-stricken state when defending her decision to step foot in the world of drugs; whereas no male protagonist analyzed in this study made mention to children as a reason to participate in drug trafficking. This demonstrates that there is a slight distinction between men and women in the drug trade. While women are generally equated to men if they are involved in the drug trade, they do retain some of their feminine characteristics, such as motherly instincts. Female protagonists in these ballads are fully capable of caring for themselves and their families and willing to take responsibility for their actions if any repercussions were to arise as a result of their involvement in the violent business of drug trafficking.

The drug ballads analyzed present drug barons as individuals who have no alternative means of employment; therefore, they are essentially forced into drug trafficking. While involvement in the drug trade is considered a method of survival, the violent measures that some protagonists have enacted are not condemned or criticized. For example, the narrators in " $L a$ venganza del MI" and "Las torturas" recognize the acts they committed as violent and brutal, but do not feel or demonstrate regret or remorse for their actions. They embrace their violent tendencies, which subsequently serve as a means to identify themselves; this demonstrates how the street code is actively present in the actions of the protagonists. Charis Kubrin cites Jaber F. Gubrium's and James A. Holstein's (1997) description of how the code of the street influences people's behaviors. Gubrium and Holstein contend that "the code [is] a living embodiment of social control, serving as a shared accountability structure for residents' actions" (Kubrin 2005; 
366). The violent environment of drug trafficking is disseminated through the lyrics of narcocorridos. These songs represent the realities that those involved in drug trafficking experience, but they do more than simply present a storyline as Luis Astorga argues. He says that, "there is no justification for their [drug traffickers'] activities, only an affirmation of situations where the primacy of the ethical codes and rules of the game at play are often disputed through gun shots" (Astorga, 1997; 10-11). While the aforementioned ballads do not justify events or protagonists' violent actions, they do celebrate them in a certain manner. John McDowell's celebratory thesis states that, "poetry about violence celebrates the deeds of the heroes who initiate and sustain violent encounters. Celebration here entails the rehashing of violent episodes in public narratives designed to exalt the noble qualities of the story protagonists" (McDowell 2000; 122). The seemingly absent criticism of violent occurrences essentially transmits the message that the protagonist's actions are justified due to underlying socio-economic circumstances. Listeners then receive this message and hear of the fortune that could await them if they were to enter into drug trafficking, almost placing the imminence of violence as secondary to the riches that can be obtained.

It should be recognized that the decision to become a drug trafficker is contingent on several circumstances, and while listening to narcocorridos may be a factor into a person's decision it is not the sole factor. The manner in which protagonist's lives are represented in drug ballads could have a convincing effect on the listener because, after all, most listeners of narcocorridos experience the same social struggle and economic exploitation as the protagonists and are from the same socio-economic strata. 


\section{CHAPTER IV}

\section{CONCLUSION}

The narcocorrido is a descendant of the traditional corrido which developed from the romance español. Stories of brutal battles, valiant revolutionary heroes, and day-to-day struggles of the people were highlighted in corridos from the revolutionary era. As the Mexican Revolution came to its end, tales of battles became more sporadic. However, corridos continued to relate stories of social struggle and political strife such as corruption, land redistribution, social inequality and exclusion, and poverty. Following the revolution, the PRI came into power; its seventy-one year reign was marked by widespread corruption. Other problems failed to be resolved such as agrarian reform, a major cornerstone of the revolution. ${ }^{23}$ At the same time, tensions surrounding the border region continued to escalate due to an increase in immigration to the United States (Pan 2006). Violence, war, poverty, and tensions with the United States were compounded in drug trafficking. As U.S. demand for drugs increased and efforts focused on dismantling larger, more powerful South American drug cartels intensified, Mexico began to emerge as a major drug producer and distributor. Ongoing poor socioeconomic conditions in Mexico only increase the allure of drug trafficking and lead to the development of an alternative social order, a narcocultura.

\footnotetext{
${ }^{23}$ Key points as to why agrarian reform failed in Mexico are identified in "Why Developing Countries Sabotage Economic Growth: Land Reform in Mexico" by Beatriz Magaloni, Barry Weingast, and Alberto Diaz-Cayeros. Instead of land parcels being granted to individuals they were granted to entire communities, which could not legally be "sold, rented, or used for collateral." Moreover, the president had direct authority regarding how land was distributed, which was inhibited by corruption (Magaloni, Weingast, \& Diaz-Cayeros 2008; 9).
} 
While there is some disaccord regarding the origin of the Mexican drug ballad, it is widely accepted that the narcocorrido emerged along the border stemming from border tensions during the time when drug trafficking began to increase in Mexico. ${ }^{24}$ A history of violence and unrest in Mexico is represented through the corrido and the narcocorrido traditions. The purpose of this analysis was to examine how Mexican drug ballads capture and reflect the presence of narcocultura in society and how the narco-lifestyle is glamorized through their narratives. This study of narcocorridos was developed using the framework established by Elijah Anderson's Code of the Street, John McDowell's Poetry and Violence, and Charis Kubrin's study of gangsta rap lyrics in "Gangstas, Thugs, and Hustlas: Identity and Code of the Street in Rap Music." First, it was necessary to discern factors that led to the development of the narcocorrido, which made it possible to examine the portrayal of protagonists, their attitudes toward crime, violence, and death, and the glamorization of the narco-lifestyle. Lastly, this study examined how women are represented through narcocorridos to determine what role they have in the genre.

Charis Kubrin's study of gangsta rap lyrics provided the format to analyze narcocorridos in the context of Anderson's and McDowell's frameworks. Elijah Anderson contends that a street code emerges in parts of society that lack an effective governing body and/or police force coupled by underlying social, political, and economic issues such as poverty, social exclusion, and lack of legitimate job opportunities. In Mexico, these problems added to corruption and have led to the perceived ineffectiveness of governmental institutions, which in turn has fostered skepticism of the government and its officials by the people. Narcocorridos reflect these circumstances in the context of narco-culture. The analysis reveals that tenets of the street code

\footnotetext{
${ }^{24}$ See Guillermo Hernández's article "On the Paredes-Simmons Exchange on the Origins of the Corrido"
} 
appear in narcocorrido narratives which may indicate that a disfunctional social order may exist in regions of Mexico and the United States where narcocultura exists and drug trafficking abounds.

John McDowell studied the relationship between poetry and violence in which he established three theses or functions of corridos in society. The celebratory thesis states that events and protagonists of these ballads are celebrated or glamourized for their violent actions. The regulatory thesis contends that corridos are "a kind of Trojan horse constructed to win acceptance through the thrill of heroic narrative, but nurturing a hidden mission, that of questioning and ultimately discouraging the indiscriminate use of violence" (McDowell 2000; 171). The therapeutic thesis discusses how corridos "transform the sentiments of those who witness their performance, and like the elegies of learned poets, corridos no doubt help people transmute their feelings of sadness and anger" (McDowell 2000; 174).

Based on McDowell's work, the analysis found the celebratory thesis to be active in the narcocorrido genre. The narcocorridos analyzed highlight the appeal of monetary gains and respect when deciding to participate in drug trafficking and in committing violent acts. However, this analysis did not reveal that the regulatory and therapeutic theses were actively portrayed through the narratives. While many narcocorridos warn of the threat or likelihood of death, they do not discourage an individual's involvement in the drug trade or the use of violence against others. Narcocorridos analyzed in this thesis seem to lack emotions of the community toward acts committed by the protagonists. Moreover, narcocorridos could have a desensitizing effect due to the glamorization of violence, the opposite of the therapeutic thesis. The absence of these two theses could be due to technological advances and the manner in which narcocorridos are produced and disseminated. For example, social media sites such as YouTube, Pandora, 
Facebook, Twitter, and Instagram, among numerous others, have aided in the distribution and propagation of narcocorridos which have ultimately led to them becoming more mainstream and pop culture than they previously were.

Additonally, the regulatory and therapeutic theses may not be active in narcocorridos because they are not a living ballad tradition. John McDowell analyzed a corrido tradition specific to the Costa Chica region of Mexico. Costa Chica corridos are what McDowell refers to as a living ballad tradition within the community. As a communal product, they reflect values and emotions of the community and its members. In contrast with corridos of the Costa Chica, narcocorridos are not a living ballad tradition, nor are they traditional corridos. The corrido tradition was generally reserved for more marginalized groups of society or were products of specific communities such as the Costa Chica. Today, people listen to narcocorridos from all social classes and by individuals who are not related to drug trafficking at all. Now, narcocorrido artists sell out concerts to tens of thousands of people throughout Mexico and the United States, this is a phenomenon not seen with traditional corridos.

There are several ways the study of narcocorridos could be further developed. The history and roles of corridistas in the narcocorrido tradition and narcocultura could be examined. Many popular drug ballad composers and artists such as Gerardo Ortiz, Jenni Rivera, and Roberto Tapia were born in and/or reside(d) in the United States. Moreover, some corridistas like Roberto Tapia have attended prestigious schools, while others like Regulo Caro hold higher education degrees. It would be pertinent to explore how artists and composers identify themselves and their roles in these aspects in order to compare their attitudes with those of corridistas from earlier years. Due to the changing environment of the music industry and to the influence of social media, it would also be worthwhile to trace how the narcocorrido has 
changed over the past several decades within itself. Traditional corridos often referenced specific names, dates, and locations of the events that they delineated. This analysis did not encounter any such examples, therefore a more in-depth study might trace the evolution of narcocorridos in the wake of technological advances. Lastly, a quantitative analysis on poverty, living conditions, and the availability of jobs and wages would further supplement the current analysis to elucidate the relationship between the narratives of narcocorridos and real world situations.

Violent content has led to narcocorridos being banned in parts of Mexico and the United States. However, narcocorridos are rather mild in comparison to the hyper-violence that is experienced in real, everyday life as a result of drug trafficking. It is necessary to identify that narcocorridos do not necessarily promote drug trafficking, instead they are an effect or aspect of narcocultura. The narcocorrido tradition transcended from the corrido, but emerged from the influence and elements surrounding drug trafficking. Ioan Grillo, author of El Narco: Inside Mexico's Criminal Insurgency, commented on narcocultura:

I don't think it's the root of the problem. It's just a symptom. If you really want to change things, you've got to change the realities on the ground. You've got to change the options for young people: the reality of a justice system, the reality of when you have neighbors with no paved streets, with the government not really existing in these neighborhoods or offering anything to young people. When they see the cartel as the only source of advancement for them - you have to change that reality. Then people can watch a soap opera about gangsters and it can be more harmless. 
While narcocorridos do celebrate violent protagonists and events, they do not explicitly tell listeners to become a narco. Taking into consideration the original thesis statement that narcocorridos capture and reflect narcultura in society and glamorize the violent nature of the drug trade, the research and analysis of this thesis concludes that narcocorridos do just that. Additionally, narcocorridos do not only reflect narcocultura, but also demonstrate how violence is becoming more acceptable in society. In other words, narcocorridos are mainstreaming violence and in the process, may be numbing its listeners to violence and crime. 


\section{APPENDIX A}

NARCOCORRIDO LYRICS 


\section{Corrido de la muerte de Zapata-Hermanos Záizar}

Escuchen señores, oigan

el corrido de un triste acontecimiento: pues en Chinameca ha muerto a mansalva Zapata, el gran insurrecto.

Abril de 1919 en la memoria quedará del campesino, como una mancha en la historia.

Campanas de Villa Ayala

¿por qué tocan tan dolientes?

es que ya murió Zapata

y era Zapata un valiente.

El gran Emiliano que amaba a los pobres, quiso darles libertad.

Por eso los hombres de todos los pueblos con él fueron a luchar.

De Cuautla hasta Amecameca, Matamoros y el Ajusco, con los pelones del viejo don Porfirio se dio gusto.

Trinitaria de los campos de las vegas de Morelos, si preguntan por Zapata

di que ya se fue a los cielos.

Don Pablo González

le ordena a Guajardo que le finja un rendimiento, y al ver a Zapata disparan sus armas al llegar al campamento.

A la orilla de un camino corté una blanca azucena, a la tumba de Zapata la llevé como una ofrenda.

Señores ya me despido que no tengan novedad. Cual héroe murió Zapata por dar tierra y libertad.

\section{Contrabando y traición - Los Tigres del Norte}

Salieron de San Isidro, procedentes a Tijuana
Traían la llanta del carro, repletas de hierba mala Eran Emilio Varela y Camelia la Tejana

Pasaron por San Clemente, los pararon la emigración

Les pidió sus documentos, les dijo de donde son Ella era de San Antonio, una hembra de corazón

Una hembra si quiere un hombre, por él puede dar la vida

Pero hay que tener cuidado si esa hembra se siente herida

La traición y el contrabando son cosas incompartidas

A Los Ángeles llegaron a Hollywood se pasaron En un callejón oscuro, las cuatro llantas cambiaron

Ahí entregaron la hierba y allí también les pagaron

Emilio dice a Camelia, hoy te das por despedida Con la parte que te toca tú puedes rehacer tu vida Yo me voy pa' San Francisco, con la dueña de mi vida

Sonaron siete balazos, Camelia a Emilio mataba La policía solo halló una pistola tirada Del dinero y Camelia, nunca más se supo nada

\section{El bandido generoso - Chalino Sánchez}

Fusilaron en la Sierra al bandido generoso Murió amarrado de un pino con un pañuelo en los ojos

El gobierno lo mató porque era muy peligroso

En Durango y Sinaloa donde seguido robaba Para ayudar a los pobres o al que lo necesitaba Después hacía lo que el tigre al cerro se remontaba

Cuarenta y ocho soldados que andaban tras de sus pasos

Todos le gritan aun tiempo - ¡Sube las manos en alto Y no trates de escaparte porque te hacemos pedazos!

Le preguntaba el teniente por que iba robando 
- No robo porque me guste tampoco me estoy rajando

Me duele ver inocentes que de hambre andan llorando

- No quisiera fusilarte por tu valor y nobleza

Pero en toditos los bancos tienen precio tu cabeza

- No se preocupe, teniente, cobre usted la recompensa

- Vas a pagar con la vida tu buena acción con la gente

- Eso yo ya lo sabía y no me asusta la muerte

En el infierno nos vemos, allá le espero, teniente

\section{EI niño de la Tuna - Roberto Tapia}

Cuando nació

Preguntó la partera le dijo

¿Cómo le van a poner?

Por apellido él será

Guzmán Loera

Y se llamará Joaquín

De niño vendió naranjas

Allá por la sierra

Nomás pa' poder comer

Nunca se avergüenza de eso

Al contrario lo dice

Que fue un orgullo pa' él

Pa' los que no saben

Quién es Guzmán Loera

Con gusto les voy a hablar

Apoyado por el

Mayo por Nacho y Juanito

Y amigos que andan por ahí

Él forma parte del cártel

Más fuerte que existe

Es de puro Culiacán

Trae la camisa bien puesta

Orgulloso lo dice

Yo soy el "Chapo" Guzmán

Mis hijos son mi alegría

También mi tristeza

Edgar te voy a extrañar

Fuiste de mi gran confianza

Mi mano derecha

Fuiste un "Chapito" Guzmán

Iván Archivaldo
Estoy de verás orgulloso

De que tú seas un Guzmán

También a tú hermano Alfredo

Saben que los quiero

Dios me los ha de cuidar

Aunque no soy tan grandote

Más bien soy "Chapito"

Muy pocos me han de llegar

Soy bravo ya por herencia

También soy amigo

Así somos los Guzmán

Un saludo pa' mi gente

de Badiraguato

Y también de Culiacán

Rancho de Jesús María

Yo nunca te olvido

Conmigo te he de llevar

\section{General de las batallas - Enigma Norteño}

Aquí vengo por el pueblo a luchar

Soy Joaquín Guzmán, El Chapo, El General

Me han comparado hasta con Francisco Villa

Porque al frente siempre traigo a mi cuadrilla

Porque estoy en pie de guerra y defiendo mi

bandera con lealtad

Me comparan aunque no soy de Durango

De Durango he adoro te arango

Yo soy de la Sierra, yo soy de la Tuna

Cuando niño no había fortuna alguna

Trabajaba yo derecho y vendía naranjas queso y también pan

Ahora yo soy dueño del triángulo de oro En sus tiempos Pancho era el mero mero En mis tiempos yo soy comandante en jefe Mis fusiles son un peligro de muerte Por ahí tengo un buen aliado mi compadre es bien arriado él es el $\mathrm{M}$

(Y al estilo Pancho Villa plebes, con Enigma Norteño de Culiacán, Sinaloa, ajaaay)

Con el tiempo poco a poco fui creciendo Y a la mafia yo le entré y le fui entendiendo Hasta que empecé a escribir mi propio cuanto Comencé con el color azul del cielo 
He pasado tempestades pero he salido adelante con esfuerzo

De los golpes de la vida yo he aprendido

Pa' merecer se tuvo que haber sufrido

A Nachito lo recuerdo con cariño

Ni se diga lo que recuerdo a mi niño

Yo marco mi territorio mis soldados dan apoyo abren caminos

Con el golpe de dos nubes cae un rayo

Compadrito no te olvido eras un gallo

Por ahí dicen que lo prometido es deuda

Acabamos con aquella lista negra

No me olviden soy Joaquín, soy el "Chapo," el general de la Sierra

\section{Mis Tres Animales - Los Tucanes de Tijuana}

Vivo de tres animales

Que quiero como a mi vida

Con ellos gano dinero

Y ni les compro comida

Son animales cretinos

Mi perico, mi gallo y mi chiva

En California y Nevada

En Tejas y en Arizona

También allá en Chicago

Tengo unas cuantas personas

Que venden mis animales

Más que hamburguesas

En el McDonald's

Aprendí a vivir la vida

Hasta que tuve dinero

Y no niego que fui pobre

Tampoco que fui burrero

Ahora soy un gran señor,

Mis mascotas codician los hueros

Traigo cerquita la muerte

Pero no se me rajar

Sé que me busca el gobierno

Hasta debajo del mar

Pero para todo hay maña.

Mi escondite no ha podido hallar

El dinero en abundancia

También es muy peligroso
Por eso yo me lo gasto

Con mis amigos gustosos

Y las mujeres la neta

Ven dinero y se le salen los ojos

Dicen que mis animales

Van a acabar con la gente pero no es obligación

Que se les pongan enfrente

Mis animales son bravos,

Si no saben torear pues no le entren

\section{El americano - Jorge Santa Cruz y Su Grupo Quinto Elemento}

Muy pocas palabras de mirada serían

Al verlo de frente intimida a cualquiera

S.A. iniciales que porta en su arma

Brillan los diamantes en cachas rameadas

Soy americano y así fui adoptado

Pero tengo rasgos de un mexicano

A los veinte años me cambié la vida

Me crucé en el fuego y recargué mis pilas

Me forjé un destino con mi escuadra Springfield

Me jugué en la suerte en un tiempo difícil

Grandes amistades hacían presentes

Hice una carrera al lado de la muerte

De noche medito y despejo la mente

En este negocio muy poco se duerme

Aspecto sereno y frases adecuadas

Arregla problemas sin disparar balas

Tuve un atentado hace algunos años

Por querer robarse a un hombre asesinaron

Las piedras se encuentran cuando van rodando

Cicatrices sanan cuando se ha vengado

Sentí la presencia y olor de la muerte

Pero la he burlado una y otras veces

Recorro el camino que he formado solo

Cuento con apoyo de los grandes socios

Los primos protegen, marcan territorio

Seguimos de frente sin tanto alboroto

Mi equipo es relax para discreción

Aún tengo recuerdos del secuestrador

Aún tengo presente fue un rescate fuerte

Pero sin rasguños regresó mi gente

Me gusta apostar en juegos de baraja

Vestir a la moda con ropa italiana

Autos deportivos y escuchar la banda 
Recorre las calles de Guadalajara

Con porte elegante siempre lo verán

Esconde su imagen por seguridad

Por Mexicali también Culiacán

En su espalda un ángel lo acompañará

Soy americano con la sangre Azteca

Mi clave y mi nombre con la $\mathrm{S}$ empiezan

Si resaltan dudas usen la cabeza

Que son de amantes esas dos letras

Investiguen mucho solo encontrarán

El nombre de Sergio y pase al más allá

\section{Estilo italiano - Jesús Ojeda y Sus Parientes}

Vestido a la moda

Y muy elegante siempre anda el muchacho

Con ropa Burberry le gusta vestir

Tiene un buen porte se hace distinguir

Será americano tal vez mexicano

Pero tiene finta de estilo italiano

Lo miran tranquilo y también preocupado

A veces sonriente, así es avelardo

Soy de Sinaloa

Al cien con la plegada, yo soy Salazar

Por clave en 90 en la organización

Me gusta el trabajo y hay dedicación

Me gusta la fiesta no voy a negarlo

Seguido amanezco con grupos tomando

Mujeres, canciones para disfrutar

Con toda mi gente, puro Culiacán

También California, Las Vegas, Nevada me tacado andar

Al fin de la misma si voy a pistear

O hablar de negocios para trabajar

También por el monte si es necesario

Allá por la Sierra yo me la rifado

Siempre acompañado yo nunca ando solo

También me acompañaba

Mi carnel el cholo

El güero bastidas me brinda su apoyo

Y también es mi amigo

Al Mayito Gordo quiero saludar

Por darme confianza también su amistad
Con el chavo Félix estoy a la orden

También con los ántrax y con mucho más

Yo no soy violento ni busco problemas

Pero me respetan y se respetar

Vestido a la moda

Y muy elegante siempre anda el muchacho

Con ropa Burberry le gusta vestir

Tiene un buen porte se hace distinguir

Será americano tal vez mexicano

Pero tiene finta de estilo italiano

Lo miran tranquilo y también preocupado

A veces sonriente, así es avelardo

\section{Venganza del M1 - Roberto Tapia}

Cobro justo liquido las cuentas

De la empresa del m y la z

Conocido como el M1

Es una clave con que se respeta

Eso grábenselo en la cabeza

Es mi vicio la sangre enemiga

La venganza se me hizo un placer

Habrá torturas, habrá un infierno

Soy sanguinario a más no poder

Me da risa mirarlos tirados

Y la tierra queriendo morder

Soy un cero un uno pa' mi equipo

El 4 fue valiente mi hijo

Fue abatido por unos cobardes

Tenían miedo de llegar conmigo

Orgullos me siento de mi hijo

Pues también le rexpidió Tashio

Con un pie presionaba su pecho

Con una mano le agarró el pelo

En la otra mano trae un cuchillo

Lo decapitó, les cortó el cuello

Y dejó junta a un mensaje

Que para los niños se respeto

Yo juré y me propuse a vengarlo

Gracias a Dios ya cumplí el encargo

Yo sé que tacho se encuentra alegre

Me siento a gusto al no defraudarlo

Pues fue un valiente con agallas

De los que hoy en día nacen contados 
Yo no maten a gente inocente El que paga aquí es el que la debe Los terceros no tienen la culpa Hay que centrarnos en los deberes Los grandes siempre contra los grandes

Ya me voy, me despido de ustedes

\section{Las torturas - Dueto Luis y Ramón}

Me quede pensando un rato

De todos aquellos

Los que he matado

Pa' ver cuál de esas muertes

He sido más sanguinario

Pues ya son bastantes

Las que me he aventado

A uno lo colgué de brazos

Se me a figuraba

A una letra "y"

Le empecé a tirar balazos

$\mathrm{Pa}$ ' que información me diera

Con lo motosierra lo corté en pedazos

Levantamos unas gentes

Y los amarramos de pies y manos

Los inke todos de frente

Como guerrillero hablado

Un rifle en cabeza y un cuchillo en mano

(Ay le ve compa Tino Acosta

Y vamos pa' Gusave, Sinaloa “viejón”)

Sacando mis conclusiones

De todas aquellas muertes que les digo

Quise ver que otras acciones

En mi vida he cometido no recuerdo algunos

Como he repetido

Al último que recuerdo

Lo enterré en un hoyo, pero estando vivo

La tierra cortó el re-suelo

Lo enterré por traicionero

Quería asesinarme, pero llegue primero

No me decidí por ni una

Todas son sangrientas

Soy el más enfermo
Voy a seguir torturando

No se anden atravesando

Yo soy de las "M"

Es más sanguinario

\section{Cuando muere una dama - Jenni Rivera}

(Pongan atención mi gente

Les tengo una petición,

Parecerá diferente

$\mathrm{Al}$ escucharlo en mi voz,

Les cantaré mis deseos

Al dejarme en el panteón,

También las mujeres mueren

Y yo quiero celebración.)

Quiero una última parranda

Por allá en mi funeral

Todos los que me quisieron

La tendrán que celebrar

Recordando mi sonrisa

Y mi forma de llorar

Fui una guerrillera fuerte

Que por sus hijos luchó

Recuerden muy bien que en vida

Su madre no se rajó

Con la frente muy en alto

Despídanla con honor

Quiero mi grupo norteño

Y que sea con tololoche

Échense un trago por mí

Y también uno que otro toque

Ya se fue la hija del pueblo

La mujer de los huevotes

(Y no me lloren mis plebes,

Ustedes nada más colecten regalías

Y mis muchachos del grupo desatado

Que siga la fumadora, ja-jaaa)

A todas mis enemigas

Que quisieron imitarme

Se acabó su pesadilla

Pero siempre han de envidiarme

Siempre fue la preferida

No pudieron alcanzarme

Amores tuve a montones 
Sé que me van a extrañar

Los que mis labios tocaron

Sé los van a saborear

Pero el amor de mi vida

Es el que más va a llorar

A mi familia querida

Mis padres y mis hermanos

Sé muy bien que en la otra vida

Volveremos a juntarnos

Para reír y gozar

De lo mucho que triunfamos

(Y no me extrañen mis jefes

Que su hija la rebelde

Por siempre vivirá, a-jaaa)

Ya me voy a otro concierto

Voy a cantar con Adán

Un dueto tengo pendiente

Por allá con su papá

Saúl Viera y Selena

También me recibirán

Que en mi lindo Playa Larga

Haya una última parranda

Y me canten mis hermanos

Mi madre flores reparta

Mi padre fotografías

Y mi hermana lea mi carta

Tomen tequila y cerveza

Que toquen fuerte las bandas

Suelten por mi mariposas

Apláudanme con sus palmas

Porque así es como celebran

Cuando se muere una dama

\section{Cara a la muerte - Gerardo Ortiz}

Cara a la muerte

Cuando llegaron las balas

No era advertencia

Ni coincidencia

Era la muerte en mi cara

Tiempo que es vida

Blanco a la mira

Asesinato me tenían rodeado

En mi mente, mi familia

En minutos repase mi vida
Puse fuerza, en mi cabeza

Subí tiro a mi 40ta

Les di pelea

Era esperado

Que me arrimaran un golpe

Cuando hay errores

Hay correcciones y

Le falle a los señores

Hice negocios

Con los contrarios

Fui un chapulín aunque debas usar

Consecuencias, que atormentan

Hay errores que nunca se arreglan

Si la muerte, comprendiera

y si el momento cambiará la escena

Que me coma la tierra

Con la fuerza paraba las balas

El impacto dio una alta descarga

No hubo tiempo de hacer el intento

Sin piedad perforaban mi cuerpo

Con mis manos tapaba mis sesos

Y la sangre corría entre mi cuerpo

Ya lo rojo en lo blanco vestía

Era la despedida

No tenía salida

Todo era blanco

Agonizaba en mi llanto

Sólo en minutos

Se aproximaba

Era el eterno descanso

Muerte en la escena

Luz de sirenas

Los agresores tomaron vereda

En segundos tocaban mi vida

Y el espacio quedo en mi familia

Solo balas y un hombre tirado

$Y$ en su cara un lienzo empapado

Era el afectado

Pobre y sin llanto

Y cantidad de rosarios

Buenos amigos

Hijos queridos

Ya les fallé en el camino

Cuerpo manchado

Entropezado

Caca de plata y un hombre encamado

Quisiera escapar de mi cuerpo 
Renacer, tener vida de nuevo

Con dolor no descansa mi alma

Sólo queda perder la esperanza

Dentro de mi caja

\section{Ya encontraron a Camelia - Los Tigres del}

Norte

Yo conocí bien a Emilio

Al que Camelia matará

En un callejón oscuro

Sin que se supiera nada

Pero los contrabandistas

Esos no perdonan nada

La banda la perseguía

En la unión americana

También mandaron su gente

A buscarla hasta Tijuana

Solo Dios podía salvar

A Camelia la tejana

Una amiga de ella dijo

Señores yo no sé nada

Pero dicen que la vieron

Cercas de Guadalajara

Mentando a Emilio Varela

$\mathrm{Y}$ dicen que hasta lloraba

La banda sin detenerse

Hasta Jalisco volaron

La buscaron en cantinas

Hasta que se la encontraron

Camelia estás sentenciada

Y de allí se la llevaron.

La entregaron con los jefes

La misión ya está cumplida

Si regresas el dinero

Te perdonamos la vida

Yo sin Emilio Varela

Para que quiero esta vida

Sonaron varios balazos

Camelia cayó enseguida

Ahora ya está descansando

Con el amor de su vida

La traición y el contrabando

Terminan con muchas vidas

\section{El hijo de Camelia - Los Tigres del Norte}

En un carro color negro, con placas de Ciudad Juárez

Se ve con mucho misterio, al transitar por las calles

El carro y quien lo maneja, su origen nadie lo sabe

Su indumentaria es sencilla, usa chamarra y mezclilla

Una mascada en el cuello, botas cowboy y tejanas

$\mathrm{Su}$ aspecto es de hombre valiente, se refleja en su mirada

La banda estaba confiada, repartiendo hierba mala,

Como a las 6 de la tarde, nadie se lo imaginaba, Que ya el Hijo de Camelia, por venganza, los buscaba

Dicen que tuvo un encuentro, con la banda de Tijuana

Dejando ahí 5 muertos, huyendo a Guadalajara Corría tan recio en su carro, nunca le pasaba nada

Lo han visto por todas partes, recorriendo carreteras

Buscando a los delincuentes, compañeros de Varela

Sigue vengando a su madre, su madre que fue Camelia

\section{También las mujeres pueden - Jenni Rivera}

También las mujeres pueden

y además no andan con cosas

Cuando se enojan son fieras

esas caritas hermosas

Y con pistola en la mano

se vuelven re-peligrosa

Con un motor muy rugiente

llegaron quemando llanta

En una trocona Blanca

pero la traían sin placas 
Dos Muchachas que venían del barrio de Tierra Blanca

En el restauran Durango de la puente California

Tres muchachas esperaban procedentes desde Colombia

Ahí quedaron de verse con las dos de Sinaloa

Todas vestían de vaquero con chamara de vaqueta

También cargaban pistola debajo de la chaqueta

Mucho dinero en la bolsa y muy buenas camionetas

Se sentaron todas juntas en una mesa tomaban

Y se metían al baño $\mathrm{y}$ andaban desaceleradas

Yo las vi cuando salían con la carita bien polveada

Por lo que pude entenderlas algo alegaban entre ellas

Creo que de billetes falsos y que mentaban la hierba

Pero se hablaban en clave para que nadie entendiera

De pronto se oyen disparos unas mujeres caían

"Las tres eran Colombianas" lo dijo la policía

Y las dos de Sinaloa a Tierra Blanca volvían

También las mujeres aunque nos duela aceptarlo
Lo digo aquí y donde quieran

porque pude comprobarlo

Que como un hombre se mueren

eso no hay que dudarlo

\section{Reina del sur - Los tigres del norte}

Voy a cantar un corrido

Escuchen muy bien mis compas

Para la reina del sur

Traficante muy famosa

Nacida allá en Sinaloa

La tía Teresa Mendoza

El güero le dijo a tere

Te dejo mi celular

Cuando lo escuches prietita

No trates de contestar

Es porque ya me torcieron

y tu tendrás que escapar

El güero Davila era

Piloto muy arriesgado

Al cartel de Ciudad Júarez

Les hizo muchos mandados

En un avión de tasesna

En la sierra lo mataron

Dijo Epifanio Vargas

Teresa vas a escapar

Tengo un amigo en España

Allá te puede hospedar

Me debe muchos favores y te tendrá que ayudar

Cuando llego a melilla

Luego le cambio la suerte

Con don Santiago Pisterra

Juntaron bastante gente

Comprando y vendiendo droga

Para los dos continentes

Manolo cespedes dijo

Teresa es muy arriesgada

Le vende la droga a Francia

África y también a Italia

Hasta los rusos le compran

Es una tía muy pesada 
Supo aprender el acento

Que se usa por toda España

Demostró su jerarquía

Como la más noble dama

A muchos los sorprendió

Teresa, la mexicana

A veces de piel vestía

de su tierra se acordaba

Con bota de cocodrilo y

Avestruz la chamarra

Usaba cinto piteado

Tequila cuando brindaba

Era la reina del sur

Allá en su tierra natal

Teresa, la mexicana

Del otro lado del mar

Una mujer muy valiente

Que no la van a olvidar

Un día desapareció

Teresa, la mexicana

Dicen que está en la prisión

Otros que vive en Italia

En California o Miami

De la unión americana

\section{La maestra del contrabando - Jenni Rivera}

Ya descubrieron que soy una dama traficante Que entró al negocio prohibido para salir Adelante y todo porque sus hijos se estaban muriendo de hambre.

Saben que soy chacalosa pa' que se meten conmigo

Me hablo de tu con el diablo tampoco puede conmigo

Mejor no le anden buscando mi poder es conocido.

Porque se enojan conmigo los que me quieren robar

Porque me busca la DEA y también la judicial Dicen que soy la maestra, no me han podido agarrar.

Si quieren saber quién soy unas pistas voy a darles
Mis guaruras son mujeres también le entran a lo grande

Todas son veterinarias cuidan mis tres animales.

Donde quiera me paseo y como quiero trabajo

Creen que soy ejecutiva pues de todo le estudiado

Recibí un bachillerato en Ciencias del

Contrabando.

No rajármele a cualquiera es herencia de mi padre

Mi valor y a inteligencia eso me heredo mi madre

Por eso me han puesto cuatros y no han podido atraparme.

Cuando andas en malos pasos la sociedad te desprecias

Si te estás muriendo de hambre nadie mira Tu pobreza mientras yo gané dinero digan todo lo que quieran.

Yo sé que me andan buscando la DEA y la Chota

En mi tierra ya saben que las mujeres la mueven Por donde quiera van a peinarme las trenzas ya tienen maestra nueva. 


\section{Bibliography}

Anderson, E. (1999). Code of the Street: Decency, Violence, and the Moral Life of the Inner City. New York: W. W. Norton and Company.

Astorga, L. (1997). Los corridos de traficantes de drogas en México y Colombia. Latin American Studies Association. Retrieved from $\underline{\text { http://biblioteca.clacso.edu.ar/ar/libros/lasa97/astorga.pdf }}$

Barragán López, E. (1997). Con un pie en el estribo. Formación y deslizamiento de las Sociedades rancheras en la construcción del México moderno. Zamora, Michoacán: El Colegio de Michoacán, Red Neruda.

Barranco, B. (2005). La Santa Muerte. La Jornada. Retrieved from http://www.jornada.unam.mx/2005/06/01/index.php?section=opinion\&article=024a1 eco

Bazant, J. (1977). A Concise History of Mexico: From Hidalgo to Cárdenas 1805-1940. Cambridge: Cambridge University Press.

Berry, S. (2012). Heroes or Villains: Placing Narcocorridos in the Mexican Corrido Tradition. Paper presented at the Phi Alpha Theta Pacific Northwest Regional Conference, Spolane, Washington.

Burgos Dávila, C. (2011). Música and narcotráfico en México. Una aproximación a los narcocorridos desde la noción de mediador. Athenea Digital, 11(1). 97-110.

Caldwell, A.A., Spagat, E., Billeaud, J., \& Weissenstein, M. (2014). Chapo’s rise: From poor, abused to cartel kingpin. News Tribune. Retrieved from http://www.newstribune.com/news/2014/mar/02/cahpos-rise-poor-abused-cartel-kingpin/

Chew Sánchez, M. (2006). Corridos in Migrant Memory. Albuquerque: University of New Mexico Press.

Craig, R. (1980). Operation Condor. Journal of Interamerican Studies and World Affairs, 
22(3). 345-364.

D.A.R.E. America. (N.D.). Mission/Vision - D.A.R.E. America. Retrieved from http://www.dare.org/mission-vision/

Day, K. (1998). Citibank Called Lax on Salinas Money Trail. Washington Post.

Dueto Luis y Ramon. (2011). "Las torturas.” Y se siente el contrapeso. DEL Records. Compact Disc.

DuBois, W.E.B. 1899 [1996]. The Philadelphia Negro. Philadelphia: University of Pennsylvania Press.

Edberg, M. (2004). El Narcotraficante: Narcocorridos and the Construction of a Cultural Persona on the U.S. - Mexico Border. Austin: University of Texas Press.

Enigma Norteño. (2012). “Generales de batalla (Joaquín Guzmán).” Generales de batalla. Fonovisa. Compact Disc.

Esparza, D., Ugues, A., \& Hernandez, P. (2012). The History of Mexican Drug Policy. Portland: Western Political Science Association.

Fehrenback, T.R. (1995). Fire and Blood: A History of Mexico. New York: Da Capo Press.

Fuentes, C. (1994). A New Time for México. London: Bloomsbury.

Gooberman, L. (1974). Operation Intercept: The Multiple Consequences of Public Policy. New York: Pergamon Press.

Gray, J., \& Johnson, D. (2013). A Companion to Media Authorship. Massachusetts: John Wiley and Sons.

Grayson, G.W. (2013). The Impact of President Felipe Calderón's War on Drugs on the Armed Forces: The Prospects of Mexico’s 'Militarization' and Bilateral Relations. U.S. Army War College Press. Retrieved from http://www.strategicstudiesinstitute.army.mil/pdffiles/PUB1137.pdf

Hart, J. (1987). Revolutionary Mexico: The Coming and Process of the Mexican Revolution. 
Los Angeles: University of California Press.

Hassig, R. (1994). Mexico and the Spanish Conquest. New York: Longman Group.

Hastings, D. (2014). Hundreds march in Mexico for release of drug lord Joaquin 'El Chapo' Guzman. Daily News. Retrieved from http://www.nydailynews.com/news/world/mexicans-demonstrate-release-drug-lord-elchapo-guzman-article-1.1703832

Hermanos Zaízar. (N.D.). "Corrido de la muerte de Zapata." N.A.

Hernández, G. (2005). On the Paredes-Simmons Exchange on the Origins of the Corrido. Western Folklore. 64(1/2). 65-82.

Human Rights Watch. (2011). Neither Rights Nor Security: Killings, Torture, and Disappearances in Mexico's “War on Drugs”. Retrieved from http://www.hrw.org/sites/default/files/reports/mexico1111webwcover_0.pdf

International Narcotics Control Board (INCB). (2012). Report of the International Narcotics Control Board for 2012. Retrieved from http://incb.org/documents/Publications/AnnualReports/AR2012/AR_2012_E.pdf

Katz, F. (1978). Pancho Villa and the Attack on Columbus, New Mexico. The American Historical Review. 83(1). 101-130.

Kellner, T., \& Pipitone, F. (2010) Inside Mexico’s Durg War. World Policy Journal. 27(1).

Kubrin, C. (2005). Thugs and Hustlas: Identity and the Code of the Street in Rap Music. Social Problems. 52(3). 360-378.

Lacey, M. (2009). In Drug War, Mexico Fights Cartel and Itself. The New York Times. Retrieved from http://www.nytimes.com/2009/03/30/world/americas/30mexico.html?pagewanted=all\&_r $\underline{=0}$

Magaloni, B., Weingast, B., \& Diaz-Cayeros, A. "Why Developing Countries Sabotage Economic Growth: Land Reform in Mexico.” Retreived from 
http://www.irps.ucsd.edu/assets/001/502977.pdf

Maldonado Aranda, S. (2013). Stories of Drug Trafficking in Rural Mexico: Territories, Drugs and Cartels in Michoacán. European Review of Latin American and Caribbean Studies. 94. 43-66.

McDowell, J. (2000). Poetry and Violence: The Ballad Tradition of Mexico's Costa Chica. Urbana: University of Illinois Press.

Mendoza, V. (1939). El romance español y el corrido mexicano; estudio comparativo. Mexico. Meyer, J. (1976). The Cristero Rebellion: The Mexican People Between Church and State 19261929. Cambridge: Cambridge University Press.

Mungaray, A. (1998). Maquiladoras y organización industrial en la frontera norte de México. Comercio Exterior. Retrieved from http://revistacomercioexterior.com/rce/magazines/345/2/RCE2.pdf

Nixon, R. (1971). The American Presidency Project. Remarks About and Intensified Program for Drug Abuse Prevention and Control. Retrieved from http://www.presidency.ucsb.edu/ws/?pid=3047

Ojeda, J. y Sus Parientes. (2011). “Estilo italiano.” Estilo italiano. Sol Musical. Compact Disc. Ortiz, G. (2011). “Cara a la muerte.” Morir y existir. Regional Mexicano. Compact Disc.

Pan, E. (2006). "U.S. - Mexico Border Woes." Council on Foreign Relations. Retrieved from http://cfr.org/mexico/us-mexico-border-woes/p9909\#p9

Paredes, A. (1958). The Mexican Corrido: Its Rise and Fall”. Madstones and Twisters, ed. Mody C. Boatright, Wilson M. Hudson, and Allen Maxwell. Dallas, Texas. Pp. 91-105.

---. (1995). Folklore and Culture on the Texas-Mexican Border. University of Texas Press.

---. (1976). A Texas-Mexican Cancionero: Folksongs of the Lower Border. Urbana: University of Illinois Press.

Paternostro, S. (1995). Mexico as a Narco-democracy. World Policy Journal. 12(1). 
Payan, T. (2006). The Three U.S.-Mexico Border Wars. Connecticut: Praeger Security International.

Purcel, S., \& Rubio, L. (2004). Mexico Under Fox. Colorado: Lynne Rienner Publishers.

Ragland, C. (2009). Música Norteña: Mexican Migrants Creating a Nation between Nations. Philadelphia: Temple University Press.

Ramírez-Pimienta, J.C. (2010). "Sicarias, buchonas y jefas: perfiles de la mujer en el narcocorrido.” The Colorado Review of Hispanic Studies. (8-9). 327-352.

Rivera, J. (2005). “Cuando muere una dama.” Parrander, rebelde y atrevida. Fonovisa. Compact Disc.

---. (1995). “La maestra del contrabando.” Reina de reinas. Sony Discos. Compact Disc.

---. (1995). “También las mujeres pueden.” Jenni Rivera y su mejores 17 éxitos. Cintas Acuario. Compact Disc.

Romo, R. (1987). "Border Culture.” The World \& I. 479-478. Retrieved from: https:/utsa.edu/president/Essays/Border $\% 20$ CultureA\%20Vibrant \%20and\%20Distinct\%20Indian,\%Spanish,\%20Mexican,\%20and\%20Amer ican $\% 20$ cultural $\% 20$ Heritage $\% 20$ and $\% 20$ Social $\% 20$ Environment.pdf

Ruiz-Cabañas, M. (1992). Mexico’s Permanent Campaign: Costs, Benefits, Implications. Drug Policy in the Americas, ed. Peter Smith. Boulder: Westview Press.

Sánchez, C. (2004). "El bandido generoso.” Colección de oro. Musart. Compact Disc.

Santa Cruz, J. y Su Grupo Quinto Elemento. "El americano.” De los Pinos a los Pinos. DEL. Compact Disc.

Schaefer, A., Bahney, B., Riley, J. (2009). Security in Mexico: Implications for U.S. Policy Options. Pittsburgh: RAND Corporation.

Shoichet, C. (2014). Capturing 'El Chapo' shows security strategy works, Mexico’s President says. CNN. Retrieved from http://www.cnn.com/2014/02/24/world/americas/mexico-elchapo/ 
Sicilia, J. (2011). Open Letter to Mexico's Politicians and Criminals. Proceso. Retrieved from http://narconews.com/Issue67/article4346.html

Simmons, M. (1963). The Ancestry of Mexico's Corridos. The Journal of American Folklore. 76(299). 1-15.

---. (1969). The Mexican Corrido as a Source for Interpretive Study of Modern Mexico (18701950). New York: Kraus Reprint Company.

Simonett, H. (2001). Banda: Mexican Musical Life Across Borders. Connecticut: Wesleyan University Press.

Sullivan, J. (2012). Criminal Insurgency: Narcocultura, Social Banditry, and Information Operations. Small Wars Journal. Retrieved from http://smallwarsjournalcom/jrnl/art/criminal-insurgency-narcocultura-social-banditryand-information-operations

Tannenbaum, F. (1950). Mexico, the Struggle for Peace and Bread. New York: Alfred A. Knopf.

Tapia, R. (2009). "El niño de la Tuna." El niño de la Tuna. Fonovisa. Compact Disc.

---. (2010). “Venganza del M1.” N.A. Fonovisa. Single.

Tigres del norte, Los. (1972). “Contrabando y traición.”

---. (1977). "El hijo de Camelia."

---. (2002). "Reina del sur." La reina del sur. Fonovisa. Compact Disc.

---. (1975). "Ya encontraron a Camelia."

Torres, G. (2013). Encyclopedia of Latin American Popular Music. Santa Barbara: Greenwood.

Tucanes de Tijuana, Los. (1995). "Mis tres animals." 14 Tucanazos bien pesados. Universal Music Latino. Compact Disc.

United States Drug Enforcement Administration. (N.D). DEA Mission Statement. U.S.

Department of Justice. Retrieved from http://www.justice.gove/dea/about/mission.html

U.S. Customs and Border Protection. (N.D.). Border Patrol Overview. Retrieved from 
http://www.cbp.gov/border-security/along-us-borders/overview.

Wald, E. (2001). Narcocorrido: A Journey into the Music of Drugs, Guns, and Guerrillas. New York: Rayo.

---. (N.D.). Corrido Censorship: A Brief History. Retrieved from http://elijahwald.com/corcensors.html

Weber, D. (1973). Foreigners in Their Native Land: Historical Roots of the Mexican Americas. Albuquerque: University of New Mexico Press. 